\title{
KOLTTASAAMELAINEN LEU'DD: SATTUMAN ENTROPIAA VAI SALATTUA JÄRJESTYSTÄ?
}

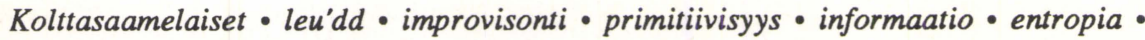
rakenteet $\bullet$ lukusuhteet $\cdot$ sääntö $\bullet$ poikkeus $\cdot$ ennalta-arvattavuus

Kansat soittavat -kirjan (Saastamoinen 1985) johdannon parissa työskennellessäni koin yhä selvemmin ongelmana löytää riittävän yksinkertaista improvisoitua materiaalia, joka siedettävällä ahertamisella voisi paljastaa mikromuuntelun jatkuvan yllätyksellisyyden sekä sen mahdollisesti tuottamat muotorakenteet makrotasolla. Edellinen takaisi musiikille suuren informaatioarvon (Kuhn 1976, 41) ja jälkimmäinen kertoisi ehkä "sattuman" takana piilevästä luovuudesta. ${ }^{1}$ Arvelin myös että improvisoinnin voimanlähteenä oleva "jatkuva taakse-jättämisen tarve" tuottaa rakennemalleja, joihin perinteiset sävelletyn musiikin analyysimenetelmät eivăt ehkä sovellu. Päätin tutkia, miten säăntő ja poikkeus vastakohtapareina soveltuisivat kuvaamaan musiikillisia tapahtumia. Etuna on se, että tämä 1-0 -ajattelumalli selittäisi kaksi tapahtumaa yhdellä teorialla. Toisaalta sääntö/poikkeus -jaksotteluun sisältyvă ennakoiminen ja erehtyminen sitoisivat analyysin musiikkiin informaationa (Moles 1971, 99).

Informaation ja kommunikaation piiriin kuuluvat sekä sääntő että poikkeus, sekä säveltäjä-esittäjä että kuuntelija. Musiikki tällaisena kahdenvälisenä "pelinä" tarvitsee lähtökohdakseen kaksi samanarvoista todellisuutta. Kysymys on sen jälkeen siitä, miten nuo kaksi voivat lähestyä toisiaan, missă määrin ennaltaarvattavuutta sisältyy "pitkien" ja "lyhyiden" sävelten epäsäännölliseltä vaikuttavaan vuorotteluun ja millä perusteella syntyvät musiikilliset odotukset (Meyer 1965, 25).

Länsimaisessa musiikissa perusasetelma on yleisesti tunnettu:huippusoinnun jälkeen odotamme perussointua. Mm. Bartók piti tătä seikkaa tärkeimpänä eroteltaessa kansanmusiikin vanhoja muotoja eurooppalaisen musiikin valtavirtauksista. Sama seikka on Leonard B. Meyerin uraauurtavan musiikkikäsityksen kulmakivenä (ibid. 54). Yllättävää sen sijaan on, että tuskin koskaan tietolähteenä mainittu Schopenhauer käsittelee samaa seikkaa lähes täysin samalla periaatteella "Musiikin metafysiikassaan" (Schopenhauer 1945, 111-113). 
Mitä sitten ei-eurooppalaisissa tai muuten vanhoissa kansanmusiikkikulttuureissa on V-I -säännön tilalla? Kysymys ei rajoitu enää musiikkiin, sillă vastausta voidaan menestykselliseti hakea niin informaatio- ja kommunikaatioteorian kuin psykologiankin piiristä. Yleistäen voisi sanoa: jos mitkä tahansa kaksi (musiikillista) ilmiötä toistuvat yhdessä (samanaikaisesti tai peräkkäin), niin toisen jälleen ilmestyessä odotamme myös toisen esiintyvän - edellyttäen että olemme huomanneet ko. yhteyden. Huippusointu-perussointu -suhde on vain yksi miljoonista mahdollisuuksista musiikillisten odotusten synnyttäjänä. Tämäntyyppiset pariyhdistelmät voidaan löytää analyysin avulla, jos korva ei niitä muuten paljasta , so. jos erot vaikuttavat văhäpätöisiltä. (Meyer 1965, 78).

Taustalla on ajatus, että mitä suppeampia musiikkipelin säännöt ovat, sitä pienemmät vivahde-erot saavat merkityksen. Jos jossain esiintyy pelkkă yksisävelikkökulttuuri, niin sen piirissä elävăt erottelevat sen, minkä meidän "rihkamakauppa-äänitearkistolla" varustetut korvamme yhdistävät (vrt. Sloboda 1986, 23). Mikrorakenteet vilahtavat kenties ohi korvien liian nopeasti (vrt. Broadbent 1958, 17), mutta ne voivat silti vaikuttaa kuulijaan tiedottomalla, alitajuisella alueella (vrt. Meyer 1965, 275-276). Kuulija ei pysty älyllisesti selittämään tällä tavalla syntyneitä tuntemuksiaan. Hän on kuin lapsi minkä tahansa musiikkikokemuksen kourissa: tuntee mutta ei tiedosta, ei osaa kuvata eikä kertoa. Musiikki hallitsee häntä tai jättää täysin kylmäksi. Sitä ei ole hänelle. Hän kieltää sen - ainakin sen arvon (vrt. Meyer 1965, 32-35).

\section{Analyysin lähtökohdat}

Analyysi on yritys opetella tulemaan toimeen musiikin kanssa, ilman tekijän tai kokijan hallintasuhdetta; vain tällă tavalla păăsee tasavertaiseen vuorovaikutukseen alkuperäismusiikin tekijöiden kanssa. Kaikki omat transkriptioni ovat alkaneet kysymyksestä ja lähes aina päättyneet kunnioitukseen.

Analyysi alkaa hidastamalla viesti, hidastamalla nauhanopeutta ja kertaamalla (vrt. Meyer 1967, 272-273), ja nämä ovat oikeastaan saman asian kaksi ilmenemismuotoa. Kertaaminen antaa lahjaksi kokonaisnäkemyksen ja hidastaminen osien mikromaailman. On siis yhdistettävä tieto ja taito, sillä jollei niitä yhdistetä, kaksi todellisuutta jää irrallisiksi toisilleen; toinen elää muttei tutki, toinen tutkii muttei elä. Maailmat kohtaavat silloin, kun toinen ei pelkästään arvaa, mitä toinen tekee, vaan osaa tehdä myös perässä sen minkä toinen on oppinut elämällä (vrt. Sloboda 1986, 5). Analyysi päättyy kuvaan. Kuvasta ei tiedä, mikä on alkua ja mikä loppua. Jos musiikki voidaan kuvata, tuo alku mieleen lopun ja loppu alun. Ne ovat samanaikaisesti näkyvillä, kuuluvat yhteen.

Sovellan nyt informaatioteoreettista ajattelutapaa musiikkianalyysiin. Tutkimuksen kohteeksi olen nyt valinnut Huotari ja Matvei Fofonofin tyttären rakkausseikkailusta kertovan leu'ddin Tämä leu'dd on yksi niistä, jotka T.I. Itkonen tallensi vahalieriölle Suonikylän ihmisiltä Koltan Lapissa kevättalvella 1913 ja jotka ovat levänneet yli 70 vuotta arkistossa kenenkään niihin kajoamatta. ${ }^{2}$ 
Leudd'eista kirjoittaa Armas Launis $(1922,32)$ teoksessaan "Kaipaukseni maa" seuraavasti:

Enimmäkseen ovat ne ikivanhoja muinaissäveleitä, vuosisatain takaisia, kuten Lapin laulut yleensä. Koltta ei kutsu niitä joiuiksi, kuten lappalaiset, sitä sanaa ei hän ensinkään tunne. Koltan laulut ovat leuddeja, koltta leuddestaa.

C.A. Gottlund $(1832,215-217)$ puolestaan kuvaa saamelaisten laulua seuraavasti:

Kuin ensin kuulin heijän laulavan, niin se kuuli minusta pian kuin tuuli oisi syvämmoassa vanhoja honkia puistellut, jotta antoivat ainian sitä yhtä ja samoa narkuttamista. Meärättyjä tai täyvellisiä eäniä ei paljo selitetäk missään, vaan yhtä naukumista tai räkyttämistä, joka yksi-eänellisyytensä kautta kuuluu kyllä rumasti. ... Koko heijän laulamuksesta ei selitetty muuta kuin kaks ääntä, ja heijän välillä yhtä rönkymistä, sellaista piammittain kuin on porsailla. Jolloin kullon vätivät tätä eäntä aivan pitkäksi, ikään kuin sillä oisivat polven kannattaneet.

Seuraavassa analyysissä keskityn pelkästään leu'ddin melodiaan ja jätän sen tekstin huomiotta.

\section{Nuottikuva esityksen tulkintana}

Nuotinnettuna analysoitavana oleva leudd näyttää seuraavalta (ks. kuva 1).

Aluksi joitakin huomioita nuotinnoksesta.

(1) Kuvan nuotinnoksen lähteenä oleva vahalieriöäänite on monessa suhteessa vaikea tulkita yksiselitteisesti. Kuuleman perustella on vaikea edes sanoa, onko sävelkorkeuden portaaton nousu (f-sävelestä c:hen) sekä samanaikainen tempon kiihtyminen $(1 / 8=170->210)$ yhteydessä lieriön pyörimisnopeuteen vai onko se alkuperäisesityksen ominaisuus. Noin puolisävelaskeleen laajuinen säveltason nousu yhden hengitysvälin sisällä noudattaa toisaalta leuddissa, joiussa ja itkussa usein esiintyvää tapaa. Koska ilmiö ei sisällä sisäistä muuntelua, voidaan se 0informaationa kuitata yhdeksi tyylipiirteeksi ja jättää taustalle.

(2) Yksittäisen sävelen mikrorakenteessa ei myöskään erotu muuntelua. Kuvan 2 kaltainen säännöllisyys on myös tyylipiirre.

(3) Äänitteen alussa on epäselvyyttä jopa ensimmäisten sävelien olemassaolosta sekä niiden aika-arvoista. Kysymyksessä voi myös olla "rytmin hakeminen", joten nuottikuva on määräytynyt yksinkertaisuuden ja yleiskuvaan sopivuuden perusteella.

(4) En ole huomioinut analyysissä 1/8:aa pienempiä aika-arvoja. Nuotinnoksessa ilmenevät pari tapausta voisivat trioleiksi kirjoittuina olla trokeemuotoisen 3/8:n mikroheijastuksia. Korva ei niitä kuuntelussa ennätä erottaa.

(5) Kaarien sijoittamiseen ei ole yleispätevää ohjetta kun on kysymys esim. saman vokaalin perättäisistä painotuksista tavun sisällä. 
Kuva 1

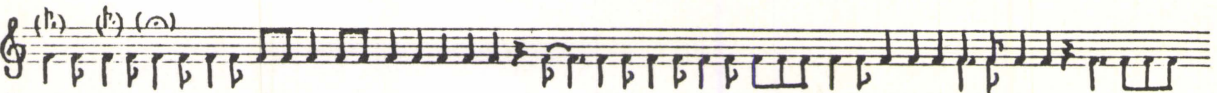

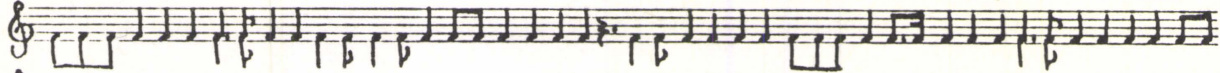

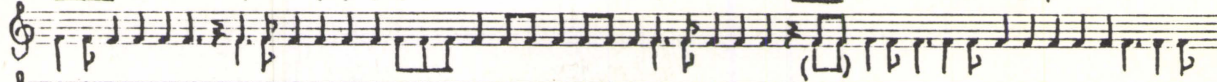

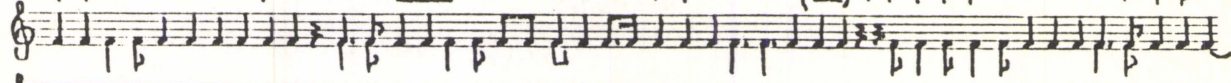

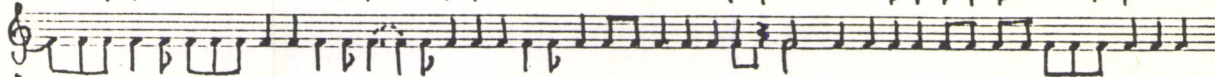

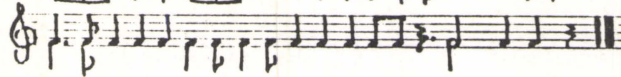

Kuva 2

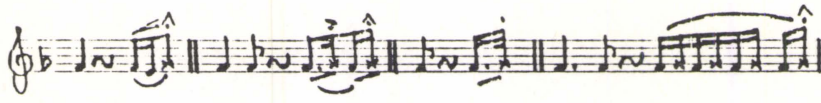

Kuva 3

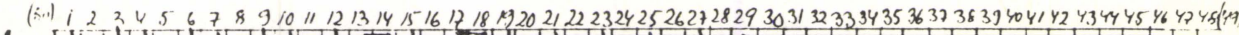
1. J D H

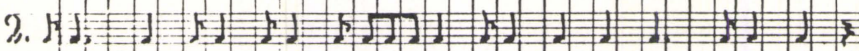

3. 1 .

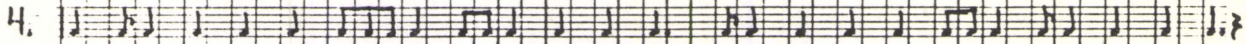

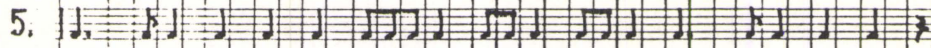

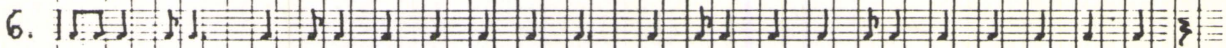

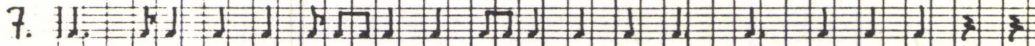

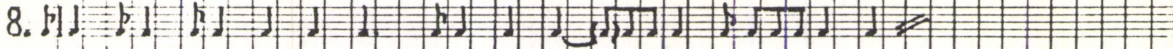

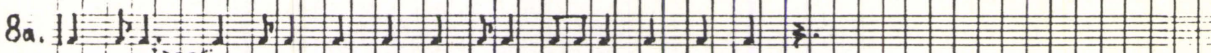

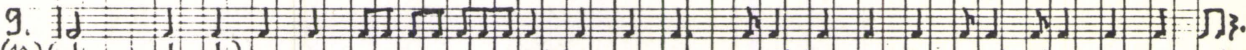

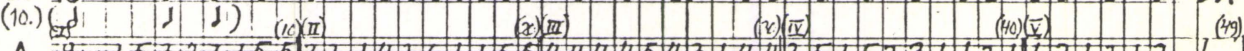

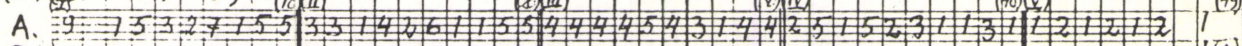

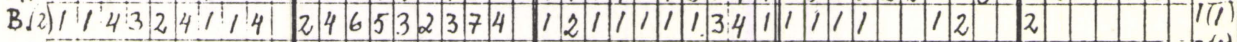

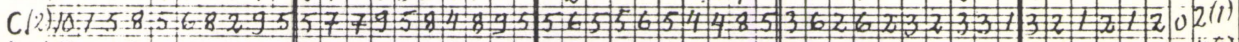

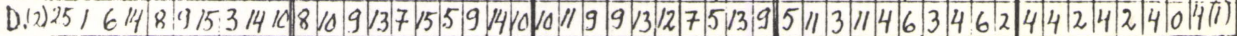

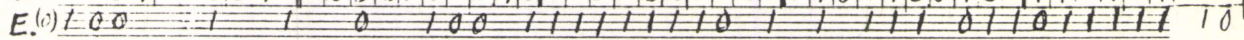


(6) Taukojen pituuksilla ei liene muuta merkitystä kuin sisäänhengittäminen. Taukojen paikat sen sijaan saattavat olla rakenteen merkkejä. (Vrt. Meyer 1967, $30)$.

(7) Vaikka laulutekstiä ei ole litteroitu, on se vaikuttanut tapaani ryhmittää săvelet iskualoksi. Epăilemättä sanojen tavumäärät ovat vaikuttamassa sävelten kestoon sekä määrään - ja sitä tietä kokonaisrakenteeseen. Tässä suhteessa tekstin vaikutus musiikkiin jäă kuitenkin odottamaan tulevaisuutta.

(8) Käytăntő on opettanut minut ajattelemaan kaksi- ja kolmijakoisuuden vuorottelua niin leu'ddin kuin joiun tai itkun rytmisen rakenteen perustana. Synkoopit kuuluvat pikemminkin musiikkiin, jonka säestyksenä on kuviteltu tai todellinen tasainen perussyke. Leu'dd on säestyksetöntä laulua ja ainakin analyysikohteessamme perussykkeen etsimisyritykset johtavat kaaokseen. Länsimainen korva vaatii joko tasa- tai kolmijakoista tahtilajia. Tästä syystä em. kolme musiikkilajia vaikuttavat meistä "rytmittömiltä". Joiun rytmiikan vaikuttaminen "selvemmältä" perustuu useimmiten lähes täydelliseen väärinymmärtämiseen. ${ }^{3}$

(9) Vain kerran esiintyvät rakennepoikkeamat on analyysissä jätetty huomioimatta. Perusteena on tulkintojen moniselitteisyys, virheen mahdollisuus sekä mahdottomuus selittää tällaista poikkeamaa sitä ympäröivästä musiikista käsin. Tällaisia ovat mm. kuvassa (12) esiintyvät (C?)A -jaksot toisen rivin alussa sekä (C?)C-jaksot seitsemännen rivin keskellä. Kahdeksas hengitysfraasi on niin paljon muita pitempi, että kuvissa $(3,6$ ja 9$)$ olen jakanut sen kahdelle riville saadakseni kätevämmin 10x10 nuotin tilastollisen otannan.

(10) Olen pääasiallisesti käyttänyt seuraavia termejä:

$y k s i k k \ddot{o}=$ iskuala $(1 / 4 ; 2 / 4 ; 3 / 8)$, jolloin painollinen nuotti tai isku on aina iskualan ensimmäinen sävel

jakso $=$ kuvan (12) osat A, B ja C

ryhmä $=$ yhden jakson tai yksikön esiintymiskertojen summa, esim. kuvan 12 pystysuorat rivit

sarja $=$ jaksojen, yksiköiden tai yksikön mikro-osien (kirjaimin tai numeroin ilmaistu) jatkumo

fraasi $=$ kahden tauon väliin jäävä jaksojen sarja, esim. rivi kuvissa 3,6,9 ja 35 mikrorakenne $=$ minkä tahansa osan sisärakenne pituus $=$ kesto

\section{Sattumaa vai järjestystä?}

Onko niin, että se mikä makrotasolla näyttää kaaokselta onkin mikrotasolta katsottuna järjestystä - ja päinvastoin? En yritä etsiä "objektiivista" rakennetta, koska näen analyysin pikemmin kuvauksena teoreettisesta kuulijasta, jolla on mahdollisuus sukeltaa sävelmän syviin hämäriin kerta toisensa jälkeen. Yhdelläkään elävän esityksen kuulijoista ei ole ollut tuota mahdollisuutta. Meillä on kuitenkin tilaisuus jälkikäteen saada aavistuksenomaisia vihjeitä niistä inhimillisen toiminnan muodoista, jotka välittyvät meille kulttuurin neitseellisesti synnyttämän lapsen - esittäjän - kautta. 
Ensialkuun ei voi tietää, onko kysymyksessä kaaos, improvisoitu sattumanvaraisuuden ilmentymä tai siltä näyttävä kokonaisuus vaiko säännöllinen säkeistörakenne joiun yleiseen tapaan. Jos sattuma-entropia nimittäin ei ole objektiivinen käsite, niin kaaos katoaa kun sen informaatio on saatettu järjestykseen; vastaavasti jos sattuma on tuotettu tahallisesti - ihmisen toimesta niin voidaanko sitä enää nimittää sattumaksi? Etsiessämme sattuman tuntomerkkejä tarvitsemme oikeastaan vain mielikuvan kruunan ja klaavan heitosta; heittokertojen lisääntyessä niiden välinen suhde lähenee jatkuvasti fiftyfifty -periaatetta, vaikka 1-0 -esiintymisjärjestys on "säännötön".

Objektiivisen musiikillisen rakenteen sijasta etsin siis pikemminkin erilaisia analyysitapoja, ja ehkä jokainen niistä kertoo jotain omasta näkökulmastaan. Samalla yritän ymmärtäă, mitä musiikista kuulijalle (esittäjä mukaanlukien) voisi tulla mieleen - ilman tekstisisällön vaikutusta.

\section{Analyysimalli}

Seuraavassa kaaviossa (Kuva 3) nuotit on jaettu hengitysfraasien mukaan riveiksi siten, että yksi ruutu vastaa $1 / 8$-aika-arvoa. Näin voimme nähdä eri fraasien reaalipituudet.

Kuvion lukutapa on seuraava:

$\mathrm{A}=$ "pitkien" nuottien yhteismäärä pystysuorassa linjassa

$\mathrm{B}=$ "lyhyiden" nuottien $(1 / 8)$ vastaava määrä

$\mathrm{C}=\mathrm{A}+\mathrm{B}$

$\mathrm{D}=$ kunkin pystysuoran rivin yhteenlaskettu pituus $1 / 8$-aika-arvoina

$\mathrm{E}=\mathrm{D}: \mathrm{C}$ eli nuottimäärän suhde kokonaiskestoon. Tämä keskimääräinen painoarvo on joko vahva $(1=2: 1)$ tai heikko $(0=1: 1)$ riippuen siitä, onko keskimääräinen nuotin kesto lähempänä neljäs- vai kahdeksasosaa.

A:n ja B:n vertailussa ovat A:t vallitsevina noin 30 tapauksessa ja B:t noin 10 tapauksessa. Riveillä 1-30 sama suhde on noin 20:10, jonka jälkeen 1/8-nuotit eivăt enäă esiinny enemmistőnä. Jos rivit jaetaan ryhmiin I-V, huomaamme määrällisen supistumisen oikealle siirryttäessä. Supistuminen on verrannollinen E:n osoittamaan "vahvojen" painoarvojen hallitsevuuteen. Merkille voi myös panna II ryhmän pitkien ja lyhyiden nuottien suhteen, joka on 1:1. $E=(D: C)$; selvästi vahvat nuotit ovat hallitsevina 50 prosentissa tapauksista (25:49) mutta heikot (0) vain 1/3 jäännöksestä. Loput ovat väliinputoajia. Yhteiskeskiarvo D:C on 1,7 , so. keskimääräinen nuotin teoreettinen pituus on pidennetty $1 / 8$-nuotti (kuva 4).

C:D ilmentää suhdelukujen hajonnan kirjavuutta: vain kerran esiintyviä suhteita on 15 , siis runsas puolet verrattuna useammin toistuviin suhdelukuihin (kuvà 5).

Ensimmäinen analyysimenetelmä tarjoaa siis kuvan lähes täydellisestä epäjärjestyksestă, jossa kuitenkin 1/4- ja 1/8-nuotit suhtautuvat makrotasolla huomiotaherättävästi. 


\begin{tabular}{|c|c|c|c|c|c|c|}
\hline & I & III & III & II & I & \\
\hline & 38 & 31 & 37 & 24 & 10 & I..... $\bar{F}=(0) 4: 3: 3,5: 2,5: 1$ \\
\hline & 21 & $\underline{36}$ & $\underline{16}$ & 7 & $2-4$ & $-\|-\sim 5: 8: 4: 2: 1$ \\
\hline (b+t) yht: & 59 & 67 & $\overline{53}$ & $\overline{31}$ & $n . \overline{14}$ & $-11-\sim 4: 4: 34: 2: 1$ \\
\hline & 105 & 100 & 98 & 55 & $n .26$ & $-11-\sim 414: 4: 2: 1$ \\
\hline & & |a| & $2: 1$ & 3;1 & n.3.1 & \\
\hline
\end{tabular}

Kuva 5

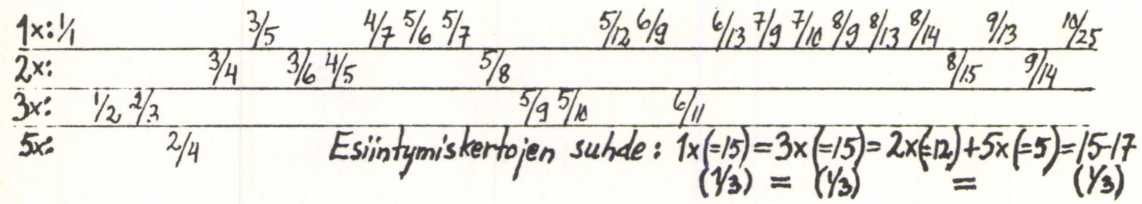

Kuva 6

I. II $\mathrm{Dx}$

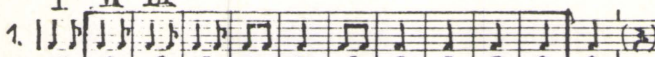

2. (3) J

\begin{tabular}{l|ll|lllllllllllll}
3 & 3 & 3 & 3 & 3 & 3 & 3 & 2 & 2 & 2 & 2 & 2 & 1 & 3 & 2
\end{tabular}

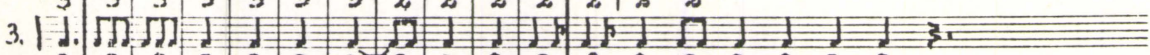

\begin{tabular}{ll|llllllllllllllll}
3 & 3 & 3 & 2 & 2 & 2 & 2 & 2 & 2 & 2 & 3 & 3 & 2 & 2 & 2 & 2 & 2 & 2
\end{tabular}

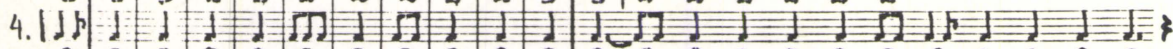

$\begin{array}{lllllllllllllllllllllllllll}3 & 2 & 2 & 2 & 2 & 3 & 2 & 2 & 2 & 2 & 2 & 2 & 2 & 2 & 2 & 2 & 2 & 2 & 3 & 2 & 2 & 2 & 3\end{array}$

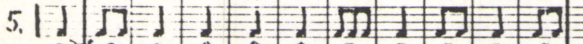

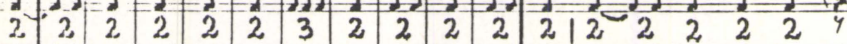

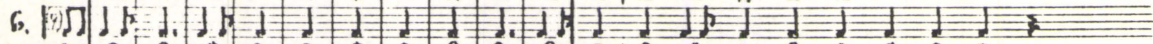
\begin{tabular}{ll|lll|l|l|l|l|l|l|l|llllllll}
3 & 3 & 3 & 3 & 2 & 2 & 2 & 2 & 2 & 3 & 3 & 2 & 2 & 3 & 2 & 2 & 2 & 2 & 2 & 2
\end{tabular}

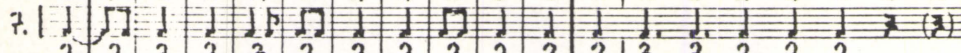
\begin{tabular}{l|l|l|l|l|l|l|l|l|l|l|l|lllll}
2 & 2 & 2 & 2 & 3 & 2 & 2 & 2 & 2 & 2 & 2 & 2 & 3 & 3 & 2 & 2 & 2
\end{tabular}

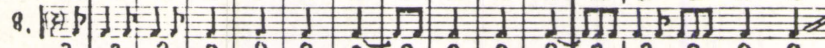
\begin{tabular}{ll|l|l|l|l|l|l|l|l|l|l|llll}
3 & 3 & 3 & 2 & 2 & 2 & 2 & 2 & 2 & 2 & 2 & 3 & 3 & 3 & 2 & 2
\end{tabular}

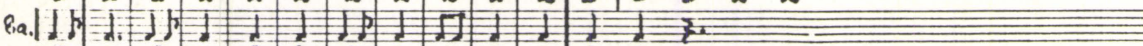
\begin{tabular}{l|l|l|l|l|l|l|l|l|l|lll}
3 & 3 & 3 & 2 & 2 & 2 & 3 & 2 & 2 & 2 & 2 & 2 & 12
\end{tabular}

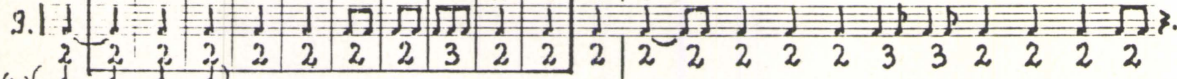

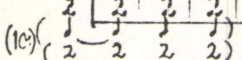




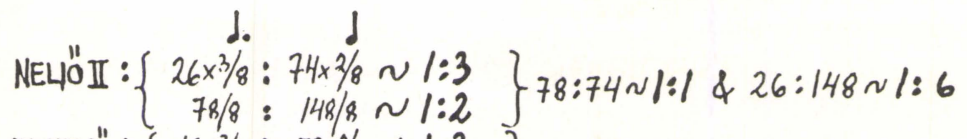
EI-NE110: $\left\{\begin{array}{cc}18 \times 3 / 8: & 59 \times 2 / 8 \sim 1: 3 \\ 54 / 8: 118 / 8 \sim 1: 2\end{array}\right\} 54: 59 \sim 1: 1 \& 18: 118 \sim 1: 6$ KAIKKI: $\left\{\begin{array}{l}44 \times 3 / 8: 133 \times 2 / 8 \sim 1: 3(!) \\ 132 / 8: 266 / 8 \sim 1: 2(!)\end{array}\right\} 132: 133 \sim 1: 1 \& 44: 266 \sim 1: 6(!)$

Kuva 8

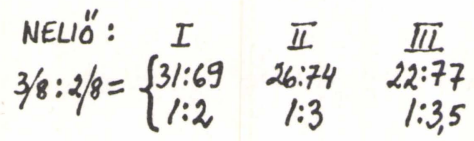

Kuva 9

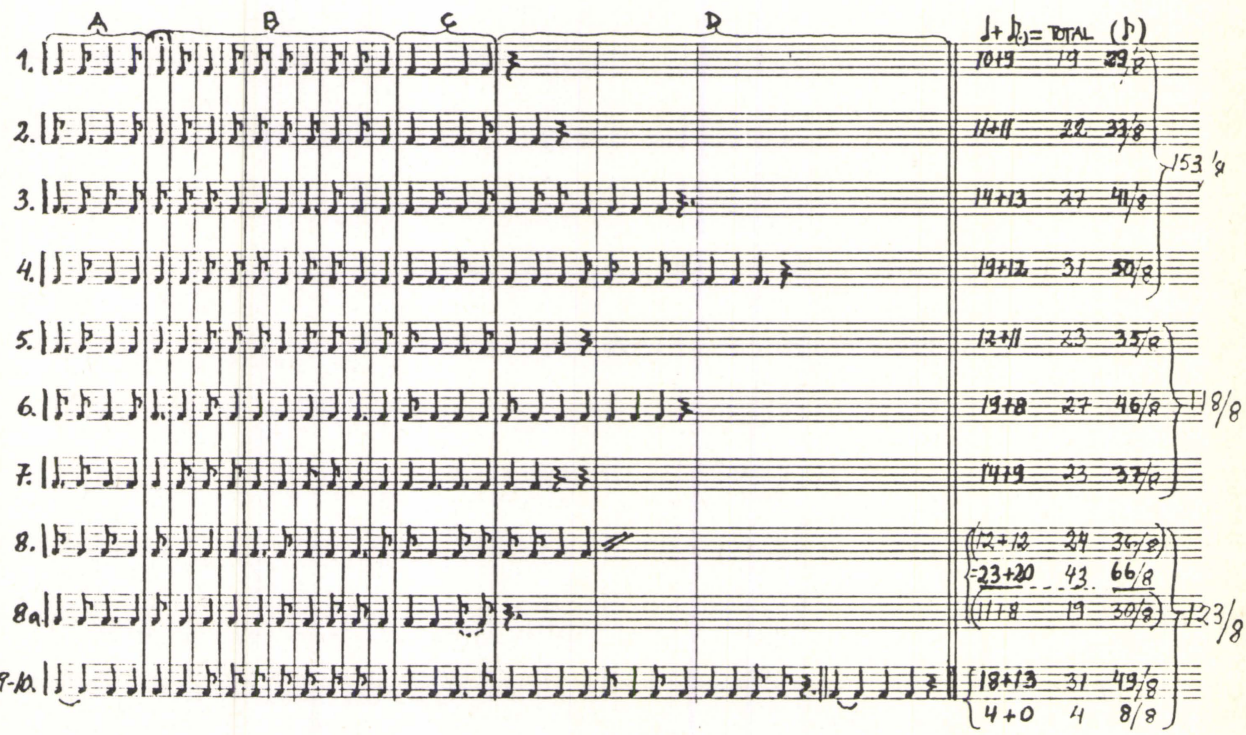




\section{Analyysimalli}

Kuvan 6 avulla yrităn selvittăă 2/8- ja 3/8-yhdistelmien sarjoja, jotka paljastaisivat mahdollisimman toistuvat 'säkeistöt' lähinnä 10x10 ruudun neliöistä I-IIIII. Tarkastelen ensin 2- ja 3-jakoisten iskualojen määrăllisiă suhteita (kuva 7):

Läpi koko sävellyksen jokaista 3/8-iskualan 1/8-nuottia vastaa yksi 1/4nuotti, kuten kuvasta 7 voimme huomata; tămä on sattuman arpapelin fifty-fifty suhde.

Siirryn tarkastelemaan 10 iskualan sarjoja huomioiden myös II-neliön molemmin puolin sijaitsevat pystysuorat rivit - siis 12 pystysuoraa ja 3x10 vaakasuoraa sarjaa à 10 iskualaa (kuva 7). Săkeistötyyppiin vihjaavia identtisiä numerosarjoja löytyy vain muutama: 333-2222222 -sarja 1-3-8 -riveillă sekä 2222-3-22222 -sarja 4-5-7 -riveillä. Symmetrian alkua saattaisi löytyä 3-4-5-8 -riveiltä, mikäli tulkitsisimme viidennen rivin 22-alun yhdeksi 3/8-iskualaksi. Vaakasuorista 30 mahdollisuudsta löydämme siis vain kolmanneksen verran toistuvia sarjoja, mikä ei vielä riitä säkeistölaulun idean pohjaksi. Pystysuorat 12 riviä puolestaan tuottavat lisäksi kymmenkuntaa uutta sarjaa. Kaikkien rivien pituus on 21-27/8 rajoissa.

Miten kaksi- ja kolmijakoisten iskualojen suhteet muuttuvat verratessamme toisiinsa I-II-III -neliöitä?

Tulos (kuva 8) toistaa vain selviön: neljäsosien määä lisääntyy suhteellisesti siirryttäessä vasemmalta oikealle.

\section{Analyysimalli}

Kuvassa 9 määräytyvät A-B-C-D 1. rivin pituuden mukaan siten, että neliö B:n koko otanta tulee mahdollisimman keskelle. Pidennetyt 1/4:t huomioidaan sekä neljäsosina että 1/8-osina; B-neliössä on kuusi "ylimääräistä" 1/8-osaa ja muualla 12. Korostan lopputulosten likiarvoisuutta, sillă yksikin tulkintaero (esim. ensimmäisen nuotinnokseni jäänteenä oleva fermaatti) muuttaa seuraavia numerosuhteita. Jos verrataan missä yhteyksissä luvut 53-106-144 sekä 40-27-2119-13 esiintyvät, on tulos mielestäni häkellyttävä. Kuvasta 10 ja 11 ilmenevä suhde tasapainottuu muutaman nuotin tarkkuudella - varsinkin jos kuvan 9 lopusta poistetaan kymmenennen fraasin alku (4/4).

\section{Analyysimalli: kaaoksesta järjestykseen}

Erottelemalla kolmijakoiset iskualat (A) sekä yhtenäinen C-ryhmä on panoarvoltaan samantyyppiset nuotit pyritty saamaan mahdollisimman selviin ryhmiin pystysuorassa linjassa. Kuvan 12 alareunassa oleva rivi 1 kuvaa pystysuorien rivien nuottimäärää ja 2 . rivi painollisten nuottien yhteispituutta 


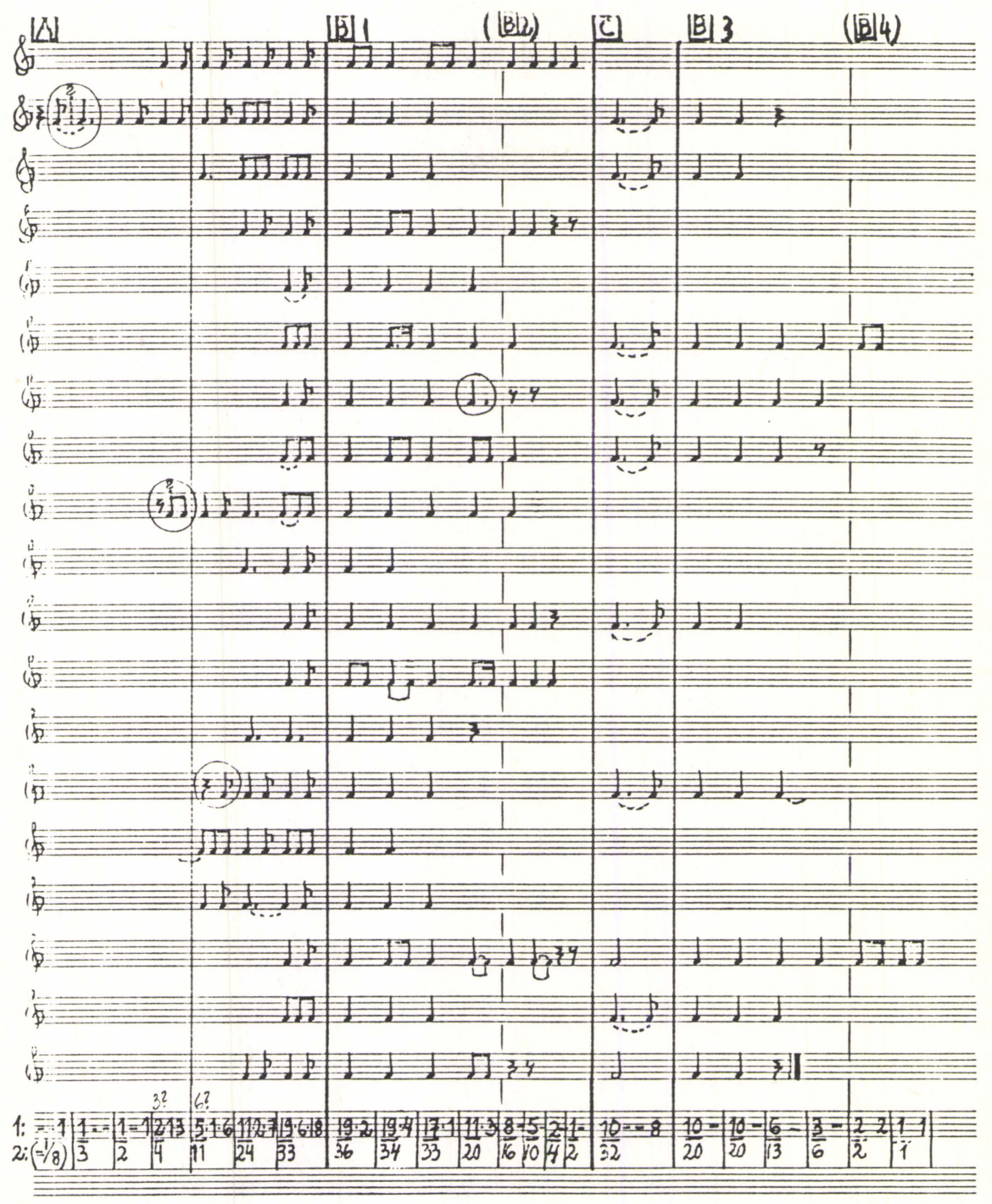

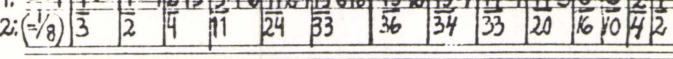




\section{$d+d$}

$A:(k p l) 24+21=45$

$\{(1 / 8) 48+21=6.9 / 8$

$B:\{(1 . p)[53+53]=106]$ $(1 / 8)[106]+53=159] / 8$

C: $\int(k p l) 27+19=46$ (1 $1 / 8)[3]+19=7.3 / 8$

D: $\left\{\left(L_{p}\right) 40+13=53\right.$ $\{(1 / 8) 80+13=9.3 / 8$

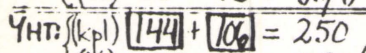
(1/8) $288+106=394 / 8$ $\overline{A C D}:\left(1 i^{\circ}\right) \quad 91+53=144$ $(1 / 8) 182+53=2.35 / 8$
Rivr 1.-5: $J=66(132 / 8) \quad A 21+C 19=D 40$ ! $\left.f_{8}\right)=56(.56 / 8) \quad A_{48}-A_{21}=C 27$ ! $y h t_{1}=122(188 / 8) \quad D 80-B 53=C 27 !$ RIVITG $-9: 10 ; d=78(156 / 8) \quad D_{40}-D_{13}=C 27$ ! $A_{1}=50(50 / 8) \quad 040-C_{19}=A_{21}$ ! $y_{h t}=128(216 / 8) \quad D_{40}-A_{21}=C_{19} !$ $B-R_{W \pi} 1,-5 ! j=23$ (46/8) $\quad D_{40}-C_{27}=D_{13}$ ! $\left.k_{0}=29\right](25 / 8) \quad$ ine... $y h t=52 \quad(75 / 8)$ B-RIVIT 6-9. $\left.\begin{array}{rl}J_{0} & =30 \\ h_{(0)} & =24\end{array}\right] \begin{aligned} & (60 / 8) \\ & (24 / 8)\end{aligned}$ $y+t_{0}=\underline{52}(84 / 8)$

Kuva 13

ISKUALOJA - PAINOLL, NUOTIT PAINOTTOMAT - YHT. KPL : KOKON. KESTO A: $1-6(3 / 8) \quad 39(-41)(77 / 8)+(10+36=) 46 / 8=(39+46=) 85 \quad(77+46=) 123 / 8$

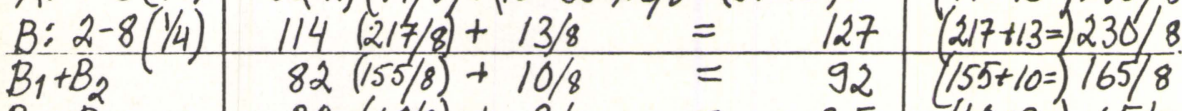
$B_{3}+B_{4} \quad 32(62 / 8)+3 / 8=35 \quad(62+3=565 / 8$

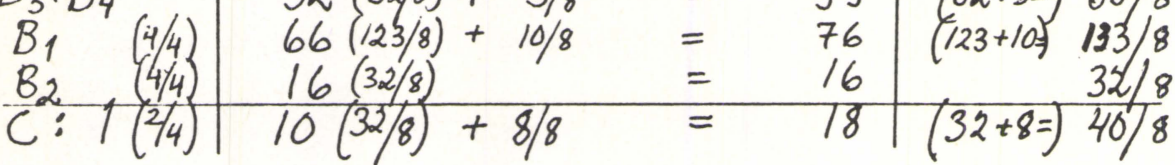

$B_{2}: B_{3-4}: B_{1}=1: 2: 4$

KOKON. NUOTTIMALARIEN SUHTEET: $A: B: C=85: 127: 18=4-5: 6-7: 1$ - $11-\quad A: B_{1-2}: C: B_{3-4}=85: 92: 18: 35$

PAINOLL. - $"-11-=39: 82: 10: 32=4: 8: 1: 3$

KOKON. AIKA-ARVOJEN SUHTEET: $A: B: C=123: 230: 40=3: 6: 1(A: B=1: 2)$ - $\quad A: B_{1-2}: C: B_{3-4}=123: 165: 40: 65=3: 4: 1: 1,5$ PAINOUL,NUOTIEN-U- - $"-\| \perp=77: 155: 32: 62=2,5: 5: 1: 2$ 
1/8-osina. ABC-jaksottelun järjestäytyneisyys on kiistaton aikaisempiin kuviin nähden. A- ja B-ryhmät ovat tilastollisesti laajenevia/suppenevia C-ryhmän pysyessä vakiona. B-ryhmät on lisäksi jaettu kahtia, jolloin 4/4 on "lyhyen" ja "pitkän" B:n rajana. Hengitystauot sijaitsevat aina B-jakson lopussa - 5 kertaa ennen A:ta ja 4 kertaa ennen $C$ :tä. Näin muodostuneet uudet rivit ovat AB- tai $\mathrm{ABCB}$-tyyppisiä. AC/CA -yhdistelmiă ei esiinny.

Kuvat 13 ja 14 selvittävät, muodostuuko $A B C$-ryhmien vălille samantapaisia numerollisia suhteita kuin aikaisemmissa taulukoissa.

Näyttää siltä, ettă painottomilla tahtiosilla olevat 1/8-nuotit eivăt merkitse mitään olennaista verrattuna painollisten nuottien mäăräsuhteisiin sekă yleensă kokonaiskestoihin. Merkillepantavia ovat sen sijaan tietyt usein toistuvat luvut, jotka sitäpaitsi ovat vielă keskenään yksinkertaisissa jakosuhteissa.

Seuraavassa muutama esimerkki:

1) ABC -nuottien yhteismäärä (230) on sama kuin B:n pituus (230/8).

2) A:n painollisten nuottien määrä (39) ja pituus (77/8) suhtautuvat B 12:sta vastaaviin arvoihin (82 ja 155/8) kuten 1:2.

3) Jokaista A:n 123/8:aa vastaa yksi BC:n painollinen nuotti $(114+10=124)$. Sama tulos saadaan B 1:n painollisten nuottien kestosta $(36+34+33+20)=123 / 8$., yhdistelmästă CB23 $(16+10+4+2+32+20+20+13+6)=123 / 8$ sekă B:n kokonaisnuottimäärässä (127). Ja lopuksi $\mathrm{AB} 12:$ n painolliset nuotit: $41+82=123$.

4) AC:n yhteinen pituus $(123+40), 163 / 8$ on B $12:$ n pituus $(155+10) 165 / 8$.

5) B2:n painollisten nuottien kesto $(16+10+4+2) 32 / 8$ on sama kuin $C: n$ painollisten nuottien kesto 32/8. Sama tulos 32/4 saadaan B 34:n painollisten nuottien määrästä $(10+10+6+3+2+1)$.

6) A:n painollisten nuottien määrä (39-41) on sama kuin C:n kokonaiskesto $(32+8)$ 40/8 sekä CB 34:n painollisten nuottien määrä (10+32) 42.

Tämä kaikki on syntynyt kertauksen välttämisen periaatteesta. Näyttăisi siltă, että säännön pakeneminen tuottaakin "antijärjestystä" - järjestystä joka tulee ilmi vasta makrotasolla. Toisin sanoen tämä makrotason järjestyneisyys edellyttäă mikrotason epäjärjestystä, jatkuvaa hajontaa, jatkuvaa yllätyksellisyyttä.

Olemme nyt valmiit esittämään ensimmäisen kokonaisrakennetta kuvaavan sommitelman, jossa näkyvät selvästi sekä mikrotason hajonta että makrotason säännönmukaisuus. Numerot ilmaisevat painollisia iskumääriä. Lisäksi $\mathrm{ABC}$ jaksojen vaihtelu on vielä kuvattu graafisesti (kuva 15).

Emme tiedä - C-jaksoa lukuunottamatta - milloin jakso muuttuu toiseksi. Voimme kuitenkin kysyä, miksei ABC-sarjoissa ole epäsäännöllisyyttä. Syynä on ehkä se, että A- ja C-iskualatyypit ovat liian samankaltaisia yllätyskontrastin syntymiseksi. Toisaalta ABCB-jaksot muodostavat sarjan 2-3-1-1-3, joka jatkuvalla muuntelullaan takaa $\mathrm{ABAB}$-jakson ennalta-arvaamattomuuden. Kyseinen numerosarja on siis uuden informaation kantaja. Tässä mielessä ei ole liioiteltua puhua "antijärjestyksestä", vaikkakaan emme voi johtaa ABCjaksottaisuutta suoraan jaksojen sisäisestä hajonnasta, numeroiden osoittamasta entropiasta. Palaamme $\mathrm{ABC}$-jaksojen sisäiseen muunteluun käsiteltyämme ensin harvinaisuuden merkitystä informaation kantajana. 
Kuva 14

$1 / 8$

PAINOLL.NUOTIT KESTO(1/8) PAINOTT. $(1 / 8)$ YHT.KPL. KOKON.KESTO (1)

(2)

(3)

$(1+3)$

$(2+3)$

\begin{tabular}{|c|c|c|c|c|c|}
\hline A : & $39-41$ & 77 & 46 & $85-87$ & 123 \\
\hline B : & 114 & 217 & 13 & 127 & 230 \\
\hline C; & 10 & 32 & 8 & 18 & $\overline{40}$ \\
\hline B1: & 66 & 123 & 10 & 76 & 133 \\
\hline B2: & $\overline{16}$ & 32 & & 16 & 32 \\
\hline B3: & 29 & 59 & & 29 & $\overline{59}$ \\
\hline B4: & 3 & 3 & 3 & 6 & 6 \\
\hline$\overline{A C}:$ & $49-51$ & 109 & 54 & 104 & 163 \\
\hline$A B:$ & 153 & $\overline{294}$ & 59 & $\overline{212}$ & $\widehat{353}$ \\
\hline BC: & 124 & 249 & 22 & 146 & 271 \\
\hline$\overline{A B C}:$ & 164 & 326 & 67 & 230 & 393 \\
\hline B12: & 82 & 155 & 10 & $\overline{92}$ & 165 \\
\hline B34: & 32 & 62 & 3 & $35_{(314=82)}$ & 65 \\
\hline B13: & $\overline{95}$ & $1 \overline{82}$ & 10 & $105^{514}=82$ & $1 \overline{92}$ \\
\hline$\overline{\text { B234 }}$ & 48 & 94 & 3 & $3=121)$ & 97 \\
\hline B124: & 85 & 158 & 13 & $\overline{98}^{10323=121}$ & 171 \\
\hline $\mathrm{AB} 1:$ & 105 & 200 & 56 & 163 & 6 \\
\hline A B 2: & 65 & $\underline{109}$ & & 103 & 155 \\
\hline AB 4: & $\overline{42}$ & 80 & 49 & $\overline{93}$ & \\
\hline CB1: & 76 & 155 & 18 & 94 & 173 \\
\hline CB3: & 39 & $91-1<2=64$ & & 47 & \\
\hline AB12: & 123 & 232 & 56 & 179 & 288 \\
\hline AB34: & $\overline{72}$ & $\overline{139}$ & 49 & $120-2$ & \\
\hline AB23: & 84 & 168 & $\overline{46}$ & 130 & 14 \\
\hline CB34: & 42 & 94 & 11 & 53 & 10 \\
\hline CB13: & 105 & 214 & 18 & 123 & 232 \\
\hline CB23: & 55 & 123 & 8 & 63 & $\sqrt{31}$ \\
\hline$A B 124:$ & 124 & 235 & 59 & $1 \overline{85}$ & 294 \\
\hline CB123: & 121 & $\overline{246}$ & 18 & 139 & \\
\hline $\mathrm{ACB} 12$ & 132 & 265 & 64 & 195 & 328 \\
\hline ACB 34: & $82-4$ & 171 & $\overline{57}$ & 140 & \\
\hline ACB 14: & 120 & 235 & 67 & 185 & \\
\hline
\end{tabular}

Kuva 17

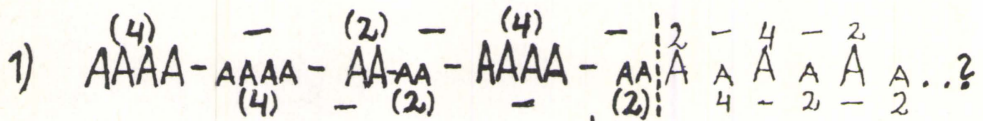

2) $4 A-4 A * 2 A 2 A 2 A * 2 A$ 2A $2 A * 4 A-4 A . ?$

3) $2 A-2 A 4 A 2 A-2 A 4 A 2 A *: 2 A ? \ldots$ 


\section{"Harvinaisuus" ja "pienuus" informaation kantajina}

Osien esiintymistiheys selviäă suhteesta A:B:C: 2:3:1. Tilastotiede kiinnittäisi huomion B:hen, mutta informaatioarvon kannalta tilanne on päinvastainen: Cjakson informaatioarvo on suuri, koska sen esiintymistiheys on kaksi kertaa harvinaisempi kuin A:n ja kolme kertaa harvinaisempi kuin B:n (vrt. Wiener 1954, 21 ja Koffka 1935, 126). Sama ilmenee painollisten nuottien keskimääräisessä pituudessa: C(3/8), A (> 2/8), B (2/8) - kuten myös jaksojen keskimääräisissä 1/8-kestoissa. C-jaksot erottuvat helpoimmin tyylillisenä kantoaaltona toimivan B:n vähäisen informaation keskeltä. A puolestaan erottuu sekoittaessaan B:n luoman säännöllisen 1/4-pulssin. Sääntö on siis tuudittaja ja poikkeus herättäjä. $\mathrm{Ne}$ ovat saman asian kaksi välttämätöntä puolta informaatiotodellisuudessa.

Muita harvoin toistuvia yksiköitä ovat kenties A:n yksinäinen $3 / 8(8 \mathrm{kpl})$, lyhyt 2/4-B (5-6 kpl), pitkät B:t (B2 ja B4 joita $10 \mathrm{kpl})$ sekä mahdollisesti Ajaksojen pidennetty neljäsosanuotti $(7 \mathrm{kpl})$. Nämä ovat kuitenkin vain arveluja, sillä tietoinen huomio voi kiinnittyä kaikkeen, mikä erottuu ympäristöstään harvainaisuutensa tai pienuutensa vaikutuksesta. Ja aina on jokin seikka huomion keskipisteenä. Tässä suhteessa mikro- ja makrotasot ovat samanarvoisia. Kysymys on vain siitä, mistä kuuntelija tavoittaa sopivan vaikeita ennakointimahdollisuuksia.

Tilastollisten suhteiden takaa yritämme nyt löytää sarjoja, joiden avulla musiikin ennakointi voisi käydä mahdolliseksi. Mikro- ja makrotaso määräytyvät sen mukaan, vertaammeko esim. yhden A-jakson pituutta ja nuottiyhdistelmiä edellisiin A-jaksoihin vai tarkkailemmeko A:n ja B:n esiintymisvuorottelua. Kysymys on joko jonkin hahmotetun kokonaisuuden sisäavaruudesta tai hahmokokonaisuuden suhteesta ulkomaailmaan.

\section{$C$-jakso $A B C$-sarjan osana}

C-jaksosta aloittaminen näyttää helpoimmalta, koska sen esiintyminen liittyy $\mathrm{ABCB}$-yhteyteen ja toisaalta $\mathrm{C}: \mathrm{n}$ sisärakenne on muuttumaton - paria loppupisteenä olevaa puolinuottia lukuunottamatta. C-sarjan selvittämisen myötä selviää samalla koko sävelmän yleinen muoto - ehkä sen teoreettinen jatkokin. Lähtökohtana on $\mathrm{ABCB}$-sarja, jota $\mathrm{AB}$-jaksot reunustavat (ks. kuva 15).

Kuvassa 16 esitän muutamia vaihtoehtoja, jotka perustuvat sarjallisuuteen tai symmetrisyyteen, so. yksi- tai kaksisuuntaisuuteen. Kaikki ovat sarjassa ilmenneiden sääntöjen loogisia johdannaisia. Mahdollisuuksia on muitakin. Oheinen malli ei vielä kiinnitä huomiota $A: n$ ja B:n pituudenvaihtelujen mahdolliseen vaikutukseen.

Kun yritetään selvittää mikä on $\mathrm{C}: \mathrm{n}$ ympäristö $\mathrm{B}$, on tässä perusvaikeutena se ettei B:n jakoa (lyhyt b/pitkä B) pystytä tekemään yksiselitteisesti $(2,3$ vai 4 iskua). Pitkiksi olen määritellyt (kuvassa 12) B2:n ja B4:n alueille ulottuvat B:t. Jako kolmen ryhmiin ei kokeilujeni mukaan tuota yksinkertaisempaa tulosta. Korostan, että seuraava pohdiskelu on pelkästään olettamuspohjaista teoriaa aina jaksoon "B-Jaksojen mikrorakenne" saakka. 
Kuva 15

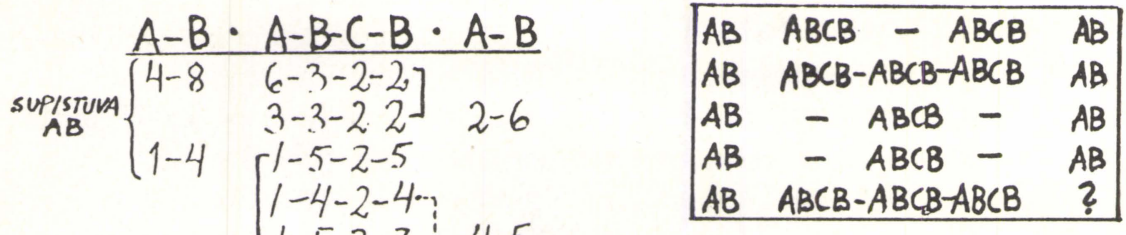

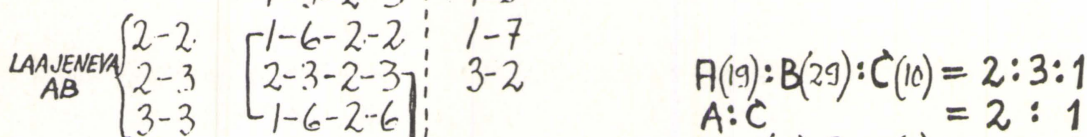

$$
\begin{aligned}
& A: C \quad=2: 1 \\
& B_{123}(29): B_{284}(10)=3: 1 \\
& B: C=3: 1 \\
& J=\frac{2-4-2-2 \cdots}{19-42-20-32 \quad 10-20} \\
& A: B\left(-B_{R: 3}\right)=2: 3 \\
& B_{(123)}:\left(B_{224}+C\right)=2: 3
\end{aligned}
$$

$10 C B$

${ }_{10 \mathrm{C}}^{19 \mathrm{~A} M A}$

Kuva 16

$2311 * 3 *(11332)$

$231 * 1 \frac{3}{3}(2) *\left(\frac{132}{231)}\right.$

$23113 *(23113)$

$2311-3 *(3-2311)$
$23-113 * 311-32$

$2311 * \frac{3}{3}(211)$

$2311-\underline{3}-(2311 * 2311-\underline{3} \ldots)$

$23-113 *(113-23)$

$B C B-B C B / B C B-B C B-B C B * B C B / B C B / B C B-B C B-B C B \ldots$ ?

$A B-(2 A B C B)-A B_{A B}-(3 A B C B)-A B A B-(A B C B)-A B A_{B}-(A B C B)-A_{B} A_{B}-(3 A B C B)$ 
C:tä ympäröivät B:t muodostavat symmetrisen sarjan:

bb-bb-BB-bb-Bb * Bb-bb-BB-bb-bb.

Jaksotus on kuitenkin erilainen 23113-sarjaan verrattuna. Päällekkäin sijoitettujina näiden sarjojen pelisääntömahdollisuudet moninkertaistuvat:

$\mathrm{bCb}-\mathrm{bCb} / \mathrm{BCB}-\mathrm{bCb}-\mathrm{BCb} * \mathrm{BCb} / \mathrm{bCb} / \mathrm{BCB}-\mathrm{bCb}-\mathrm{bCb} \ldots$ ?

\section{A-sarja}

Lyhyt "a" kulkee 4-2-2 -sarjana ja pitkä "A" 4-2-4 -sarjana. Kuva 17 on annettujen sääntöjen puitteissa jatkettu teoreettinen mahdollisuus, mutta vain yksi monista:

Mitä tapahtuu $\mathrm{ABCB}$-sarjojen välisissä $\mathrm{ABAB}$-sarjoissa? Jos erotamme 3/8mittaisen "lyhyen $A: n "$, saamme sarjan:

$A B-(2 A B C B)-A B a b-(3 A B C B)-A B a b-(A B C B) a B A b-(A B C B)-A b A b-(3 A B C B)$

$A$ ei siis esiinny irrallaan ympäristöstäăn vaan sijoittuu joko $A B: n$ tai $C B: n$ jälkeen. Sillä voi myös olla jonkinlainen suhde B:n pituuteen:

- Lyhyen a:n ympäristö (AB) a (B) -sarjassa: Bb-bB-bB-bB

- Lyhyen a:n ympäristö (CB) a (B)-sarjassa: Bb-bB-bB-Bb.

Eroa on vain viimeisessä yhdistelmässä, joka jatkossa on oikeutettu muuntelumahdollisuuteen.

A:n ja C:n vuorottelu BAB:n edellä on selkeä: AA-CC-AC-AC. Pitkän A:n edellä oleva $\mathrm{AB}$ - tai $\mathrm{CB}$-yhteyden sarja on puolestaan $\mathrm{AC}-\mathrm{CC}-\mathrm{AA}-\mathrm{AC} * \mathrm{AC}$, joka voisi olla käänteinen lyhyen a:n ympäristösarjalle (kuva 18).

Pitkän A:n Bb-ympäristökaava yksinkertaistuisi, jos arvioisimme aivan ensimmäisen $\mathrm{Bb}: \mathrm{n}$ esittelyyn liittyväksi poikkeukseksi ja korvaisimme sen bb:llä. Saisimme tällöin kaksi kaunista symmetriaa:

(AB)A(B)-sarja: bb-Bb-Bb-bb*bb...

(CB)A(B)-sarja: bb-bB-bB-bb*bb...

Aa:n pituus sekä ympäristö näkyvät kuvasta 19.

\section{B-sarja}

C:n osalta B:n pituus on jo määritelty, mutta entäpä $A$ ? Saamme sarjan ABAABa-aba/ ABA-Aba-aBA/ AbA-AbA-Aba (kuva 21 alarivi). Jos erottelemme B:n vasemman puolen A:t, saamme symmetrian AAaA-AaAA*A. Oikealta puolen syntyy sarja AaaA-aA-A-Aa, siis kaksi symmetriaryhmää.

Entä $\mathrm{B}$ itse? BBbB-bBbb*b on käänteissymmetria. Täydellinen Bb-sarja näyttää monimutkaiselta, mutta pitämällä $\mathrm{AB}: t$ ja $\mathrm{CB}: t$ erillään säilyy rakenne siedettävän yksinkertaisena. Kuvassa 20 on huomioitu vain B:n pituudet. Kuvassa 21 on C:tä ja lyhyttä a:ta ympäröivä B-sarja huomioitu siten, että B:t on merkitty erikseen jokaiselle A:lle ja C:lle. Limittäistapauksissa kaksintuneet B:t on yhdistetty kaarilla. Keskirivissä ovat symmetrian sekoittavat pitkät A:t. Perusongelma tällaisessa hahmotuksessa on se, milloin jatkuva AB-sarja koetaan parillisena $(\mathrm{AB}-\mathrm{AB})$ tai symmetrisenä $(\mathrm{AB}+\mathrm{BA}-\mathrm{ABA}$ ja $\mathrm{BA}+\mathrm{AB}-\mathrm{BAB})$. 
Kuva 18

$$
\begin{array}{lll}
\text { LYHYT } A:-A A-C C-A C-A C *(A A-C C-A C-A C \ldots) & (A=A B A B) \\
\text { PITKA A: } A C-C C-A A-A C * A C-C C-A A-A C * A C \ldots & (C=\bar{C} B A B) \\
-11-: ? A-C C-C A-A A * C A-C C-C A-A A * C A \ldots \\
-11-: ? A-C C-C A-A A-C A * C A-C C-C A-A A-C A *
\end{array}
$$
(A)BAB-SARJA:
(C) $B A B--11-$ :
$\underline{B} B-B_{B}-B_{B}-B B * B B \ldots$
$B B-B B-B B-B B * B B \ldots$.

Kuva 19

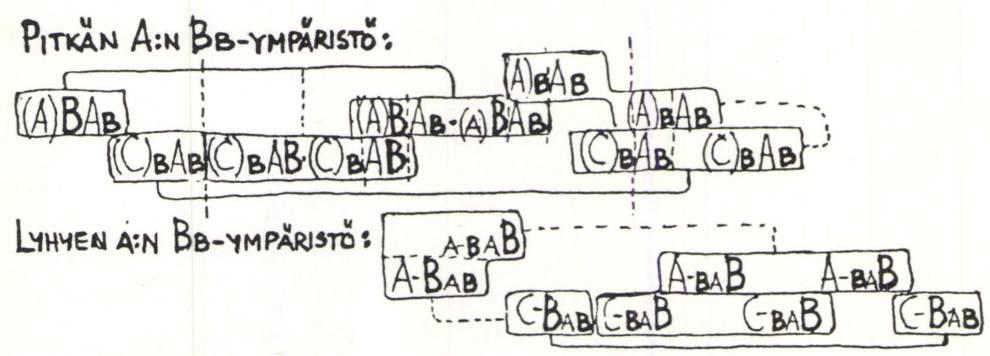

\section{ABC- SYMMETRIA:}

$A B A b-A b \quad A B a b a B-a b \quad a B \quad A B A b a B=a B A b A b-A b-A B a B-a b-A b-b$

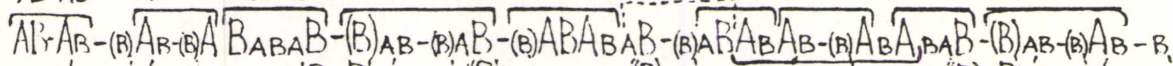
(B)CB: $(B) C B$ :
BCB: (B)CB: (ABCB:
(B) $C$ :
(B)CB:
$(R) C B::(B) C B:(B) C B:$

Kuva 20

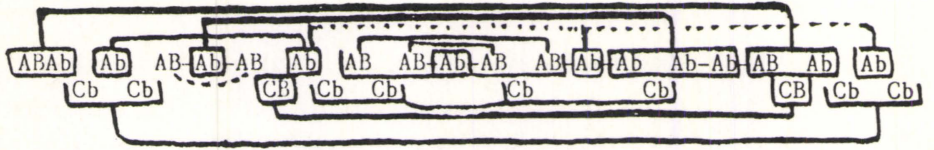

Kuva 21

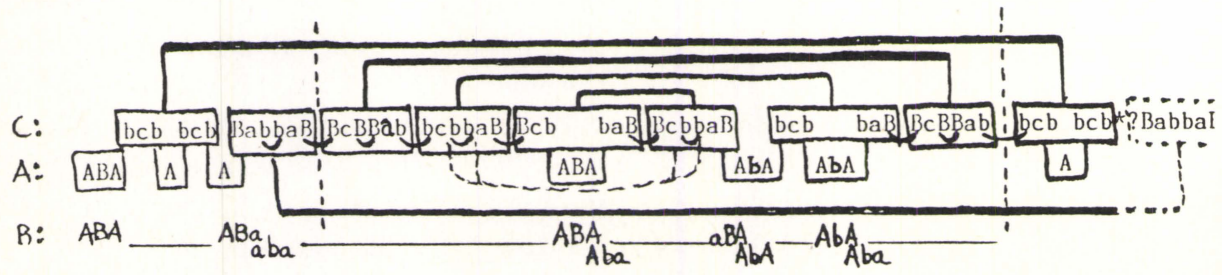


$\begin{array}{lllllll}1 & 2 & 3 & 4 & 56 & 78 \\ A & B & A & B\end{array}$ (VIVIT 187: $A_{A} A A(-A-) A_{A} A(T A 1) A A-A A-A_{A}-A A * A$

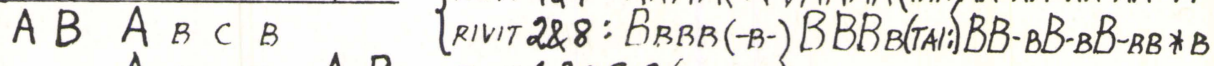
$A B C$ B $A B$ RIVIT 1-2\&7-8 (LAAKA.S):

$A$ A $B C B$ ABAB-ABAB *ABAB-ABAB$* A_{B}$ $A B C B \quad T A l: A B A B * A B-A B-A_{B}-A B * A_{B} A_{B}-A_{B}$

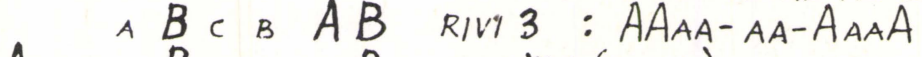

$A B \quad A B C$ B A B RIVIT $4 \& 6$ (VAAKAS.):

$A B A B C B \quad A_{B}$

$A$ B $A B C B$

(PYSTYS.)

$A B C B$

RIV 4: $\quad B B B_{B}\left[\left.\overline{B B}\right|_{B} R_{B B}\right.$

$A B C B$

RIVI 6: $B B B A B B$ BB BB

\section{Kuva 23}

\begin{tabular}{|c|c|c|c|}
\hline $\begin{array}{c}A_{B C B} \\
A_{B C B} \quad A B C B \cdot A B C B \\
{ }_{A B C B} \\
A B C B\end{array}$ & TAl: & $\begin{array}{l}A_{B C B} \\
A B C B \cdot A B C B \cdot A B C B \\
A B C B \\
A B C B\end{array}$ & $\begin{array}{l}A_{A}=21 d_{0}(+4)(K A K K I) \\
B_{B}=36 / 4 \\
\left.B_{B}=36 / 4(+2)(K A I K K I=8+53 / 4)=53 / 4\right)\end{array}$ \\
\hline $\begin{array}{l}A B C B \\
A B C B\end{array} \quad A B C B \cdot A B C B$ & & $\begin{array}{l}A_{B C B} \cdot A B C B \cdot A B C B \\
A_{B C B}\end{array}$ & $A_{A}=17 \delta_{0} \quad(K A I K K I)$ \\
\hline
\end{tabular}

Kuva 24

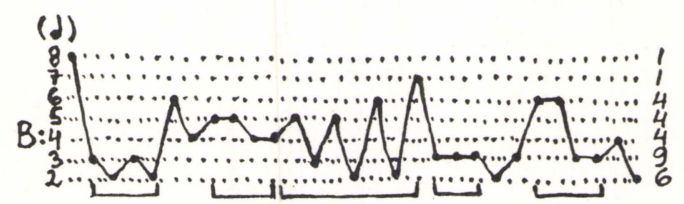


$B: N$ d-SARJA:

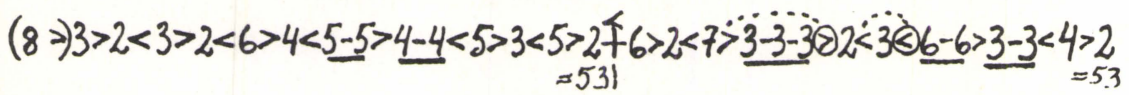

Kuva 26

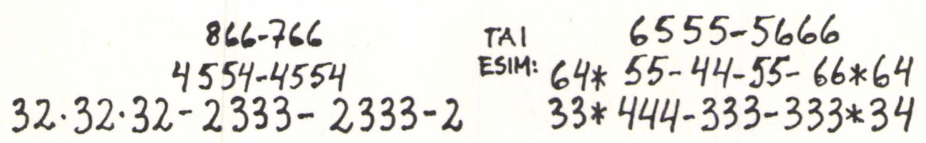

Kuva 27

$C B C(1): 5-17-9-9-16-15-14-9-7$

$C A+B C(1): 8-21-10-10-23-20-21-10-9(-2),(=\sim 4 \times 20 \& 5 \times 10)$

Kuva 28

$B: \Omega J(3-4)+d \Omega(7-9)+\Omega(3-4)=\sim 30 / 4$ (FTOTAL $\sim 90 / 4=\sim 120 / 4)$

$d-1 \delta-\Pi-1 .-\pi]-d+d . \delta$

MÄÄRÄ: $\sim 100 \quad \sim 25 \quad 13-16 \quad 7-8 \quad 7-10 \quad 8-10 \quad 1=$ SUURI INFORMAATIOARVO

SUHDELUKV: 12 2 $4211112=$ PIENI - 1 (-TYYLIPIRRE)

Kuva 29

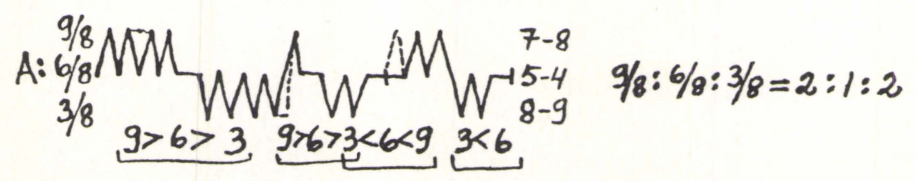

84 
Kuvan 22 rakennekaaviossa A:n ja B:n pituudet on huomioitu. Kuvio näyttää toistaiseksi parhaiten ja yksinkertaisimmin järjestävän mahdollisimman monta osatekijäă mielekkäăsti. Symmetrioiden ja sarjojen erimittaisuus tekee săvellyksestă loputtomasti muuntelevan "polysymmetrisen" jatkumon. Sarja tarjoaa ennalta-arvattavuutta, kun taas symmetria tuottaa yllätyksiä ja entropiahajontaa. Itse asiassa nämä mallit ovat 2- ja 3-jakoisuuden makrotasokerrannaisia .

Kauneimman muotonsa saa $\mathrm{ABCB}$-sarja kuitenkin jättäessämme reuna-AB:t pois. Symmetria on lähes täydellinen myös ajallisesti (kuva 23).

\section{B-jaksojen mikrorakenne}

Tähän mennessä olemme puhuneet vain summittaisesti lyhyestä/pitkästä B:stä. Muutama esimerkki valaisee sisärakenteen tutkimisen näkökulmia lähtökohdan ollessa: "kaikki voi suhtautua kaikkeen". B:n 1/4-nuottisarja on suppeneva ja laajeneva. Jos jätämme 8/4-johdannon pois, on sarjan molempien puoliskojen summa $53 / 4$ (kuva 24 ja 25 ).

Jakamalla numerot kolmeen pariin $(8-6,5-4,3-2)$ mutta säilyttämällä esiintymisjärjestyksen huomaamme yllättävää säännönmukaisuutta (kuva 26).

Mitatessamme kahden C:n välissä olevat B- ja A+B -iskut huomaamme jälleen supistumista (kuva 27).

Ilman laulutekstin apua B-jaksojen sisäinen rakenne sekä siitä syntyvä sarja näyttäă olevan liian vaikea pala selvitettäväksi. Olisi tunnettava sanojen tavuista syntyvä mikrorakenne. Kukaan ei voi pelkän musiikin perusteella yksiselitteisesti sanoa, millaisiin ryhmiin peräkkäiset neljäsosat hahmottuvat kuulokokemuksessa. Ainoa mitä voimme tehdä, on tutkia kahdeksasosien esiintymistä neljäsosien keskellä. Tällaisia yksiköitä on tulkinnasta riippuen 13-17. Ne esiintyvät yksittäisen B:n sisällä seuraavasti:

$2-1-1-1-2 * 2-1(3)-2-1$

Jaettuna kolmeen tyyppiin tällaisten 1/8-yksikköjen yhteiskesto on 30/4. Kuvassa 28 verrataan kaikkia iskualatyyppejä toisiinsa.

\section{A-jaksojen mikrorakenne}

Jakaessamme A:t kolmeen pituusryhmään saamme niiden välisiksi suhteiksi 2:1:2. Niiden keskinäistä järjestystä kuvaava sarja supistuu ja laajenee. Ilmiö on vastaavan B-sarjan "hidastettu" heijastus makrotasolla (kuva 29).

Yksiköiden sisäinen hajonta jakautuu myös kolmeen tyyppiin, joista keskimmäinen (trokee) toimii tyylipiirteenä, kantoaaltona. Sen väleihin sijoittuvat 3-1 -tyypit seuraavasti: 1-3133-3313-111-3313 (kuva 30).

Kokonaisuutena A-sarjan mikrorakenne on jälleen niin monimutkainen, että nähtävästi ainoastaan sanojen tavumäärät voivat antaa valoa 123-tyyppien muuntelusarjaan. Jos katsomme sarjan numeroita katkoista välittämättä, saamme 
pariyhdistelmät, joissa 2-3 perustyyppiä hallitsee puolta kaikista tapauksista. Toistuuko sama seikka sävelmien kaikissa yhdistelmissä? (kuva 31)

Jokaisella sävelellä on menneisyytensä ja tulevaisuutensa tietyn sääntömaailman vuorovaikutuspiirissä. Jossain märin pystymme arvioimaan sen mahdollista tulevaisuutta sen aikaisemmista tekemisistä ja kokemisista käsin. Inhimillisen toiminnan ilmauksena jokainen tehty valinta ("sävelen teko") laajentaa tai kertaa sen omaa menneisyyttä - joskus jopa pelin sääntöjä supistamalla (kuva 32).

Kuvasta 32 selviävät osien sisäiset tyylipiirteet (eli enemmistötapaukset) sekä osien saumakohtien liittyminen toisiinsa. Voimme siis nyt puhua tilastollisista tyylipiirteistä; muutama perustyyppi kattaa noin puolet kaikista tapauksista ja loput hajoavat yksittäisilmiöiksi. Joskus kaksi tyyppiä vuorottelee tasapäisesti hallitsevassa asemassa. Kahdeksan tärkeintä yhdistelmää (A-H) kattaa noin 60 esiintymiskertaa, kun taas loput (noin 24) yltävät vain 40:een. Taulukoissa A1-G1 on kuvattu yhdistelmien alajakoja laajemmissa yhteyksissä. Samoin on laita kohdissa I-J sekä osittain F-H.

Lopuksi katsomme vielä $\mathrm{AB}-\mathrm{ABAB}-\mathrm{ABCB}$-sarjojen välisiä pituuksia. Jos ensimmäinen $\mathrm{AB}$ on itsenäinen, seuraa sitä $14 \mathrm{ABAB}-$ tai $\mathrm{ABCB}$-sarjaa. Painollisten nuottien määristä syntyy sarja, jonka osien keskipituudeksi tulee 11 iskua +11 iskun ylijäämä. Pituudet ovat hämmästyttävän samankaltaisia (kuva 33).

Toinen lähtökohta on kuvan 12 jaksotus, jossa AB:t on huomioitu erillisinä pareina. Tällöin tulee uudelleen esille sarjojen supistuminen ja laajeneminen. Se on A- ja B-sarjojen "hengityksen" toinen makrotaso (kuva 34).

Löytyykö supistumisen ja laajenemisen merkitys itse informaation käsitteestä: toistuessaan "ymmärretyn" hahmon kuulijalle tarjoama informaatio pienenee (Wiener 1954, 21). Näin ollen supistuva sarja (aikaa "jouduttaessaan") auttaa kuulijan mielenkiinnon säilymisessä. Toisaalta myös esiintyjä itse kyllästyy vähitellen toistamaan sarjaa samanpituisena. Psykologisesti samanmittaiset ajanjaksot ovat tässä tapauksessa reaalisesti lyheneviă. Hyppäys takaisin pitkään sarjaan merkitsee yllätystä, joka ennen pitkää johtaa vastayllätykseen sarjan laajenemiseen.

\section{Hengitystaukojen mukainen jaottelu: sarjojen supistuminen ja laajeneminen}

Taukojen vaikutus rakenteeseen on ollut vaikea ratkaista. Ratkaisun avaimena on A:n ja C:n yhdistäminen "pitkä sävel"-käsitteeksi - vastakohtana B:n 1/4 nuotille. Ryhmittely on hätkähdyttävä (kuva 35).

Kuvasta huomaamme seuraavaa:

1) Taulukon numeroiden osoittamat jaksojen sisäiset pituudet suosivat tiettyjä iskuryhmiä: 236-145-126-23-136-234.

2) Pystysuorissa riveissä on sama suosikkijärjestelmä.

3) C-jaksojen tasainen hajonta on merkillepantava. 
(3) $\prod \backslash \rightarrow$

SARSA:2222-0/22-232-13322-2323-02/3-122211-022-323-2/2-2322

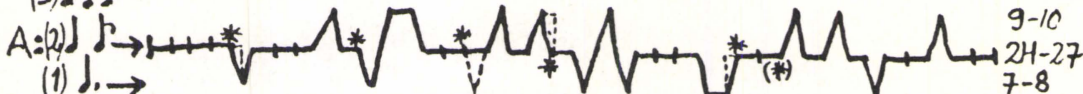

ENNEN B-OSAA $1 \times d .-6 \times \sqrt{J}-12 \times d$ d

Kuva 31

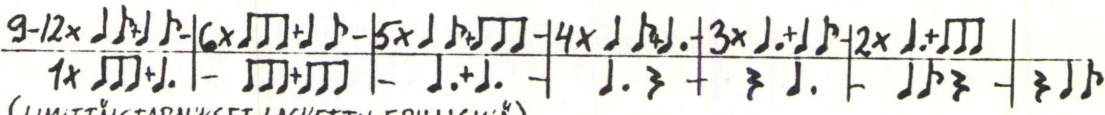

(LMITTÁ/STAPALKSET LASKETTU ERIUISINAA")

Kuva 33

$A B-A B C B-A B C B-A B A B-A B C B-A B C B-A B C B-A B A B-A B C B-A B A B-A B C B-A B A B-A B C B-A B C B-A B C B$ $\begin{array}{lllllllllllllll}12 & 13 & 10 & 13 & 13 & 11 & 11 & 13 & \| & 13 & 11 & 11 & 15 & 9 & 10\end{array}$

Kuva 34

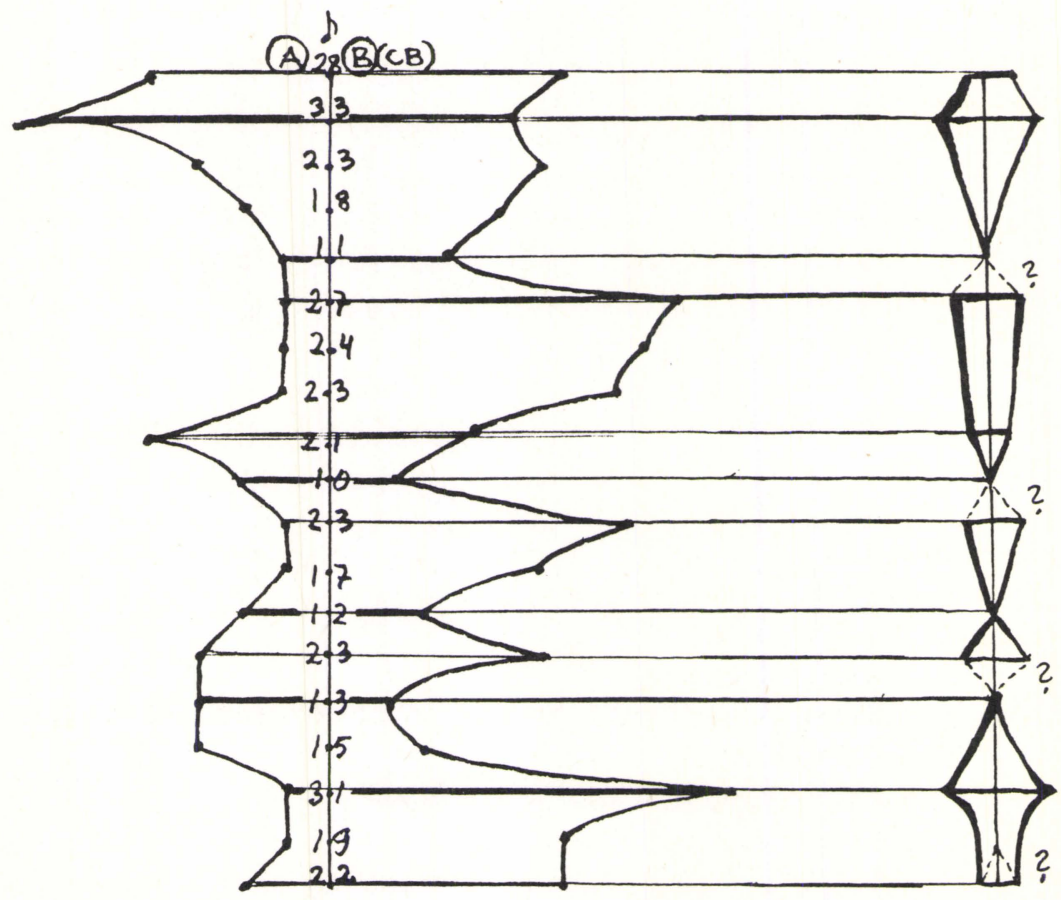



A) $\frac{10-12 \times d d \rightarrow d}{8 \times d d \rightarrow d \frac{d}{d j}}$

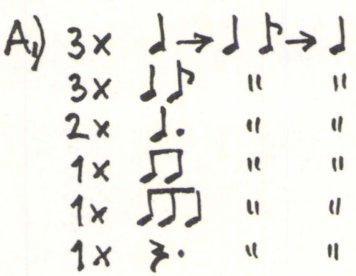
c) $\frac{6 x \text { गI] } \rightarrow \text { J J }}{2 x}$
$1 x " 1 x "$ ग

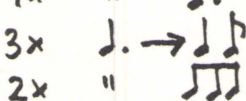
B.) $3-4 x d \delta \rightarrow d d \rightarrow d 5$
$2 x d \mid n$ "
$1 x$ d. " "
$1 \times 32 " 1$
1x "1.

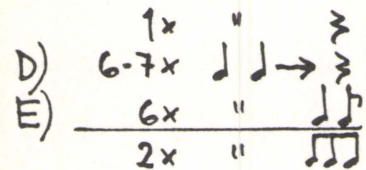
c) $2 \times d \frac{d}{1 \times d J] " d I} \rightarrow d$
$1 \times$ गु " "
$1 x d 8$ " "
$1 \times$ d. "
F) $\begin{aligned} & 1-2 \times 1 \| \\ & 6 \times d \rightarrow d . j \rightarrow d j \\ & 2 \times 3 \rightarrow d \rightarrow d j \\ & 2 \times 3 \rightarrow d . j \rightarrow d j\end{aligned}$

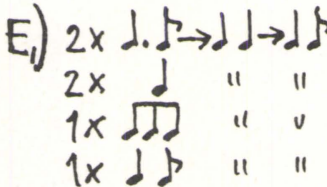
G) $\frac{9-10 x \quad \square \rightarrow \frac{1}{3}}{1-2 x}$

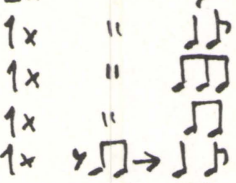
H) $\begin{gathered}3-5 \times \prod_{2} \rightarrow d \rightarrow \Omega_{11} \\ 2 \times d \delta=11\end{gathered}$
$2 \times$ ग "
$1 \times \Omega \rightarrow d \rightarrow$. $\delta$
$2-3 \times 3 \rightarrow d 5$
$1 \times 3 \rightarrow d$.
$1 \times 3 \rightarrow \Omega$
G) $7-8 \times d \rightarrow \square \rightarrow d$

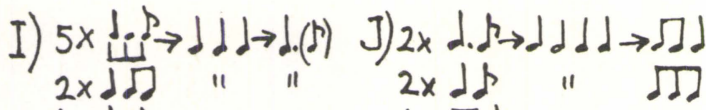

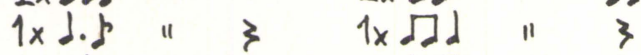

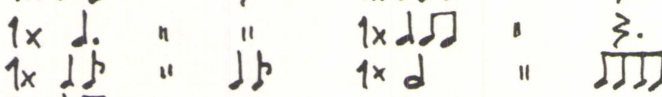

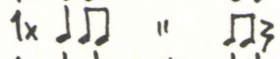 $1 x$ d.s 1 d 1xd 11 त 


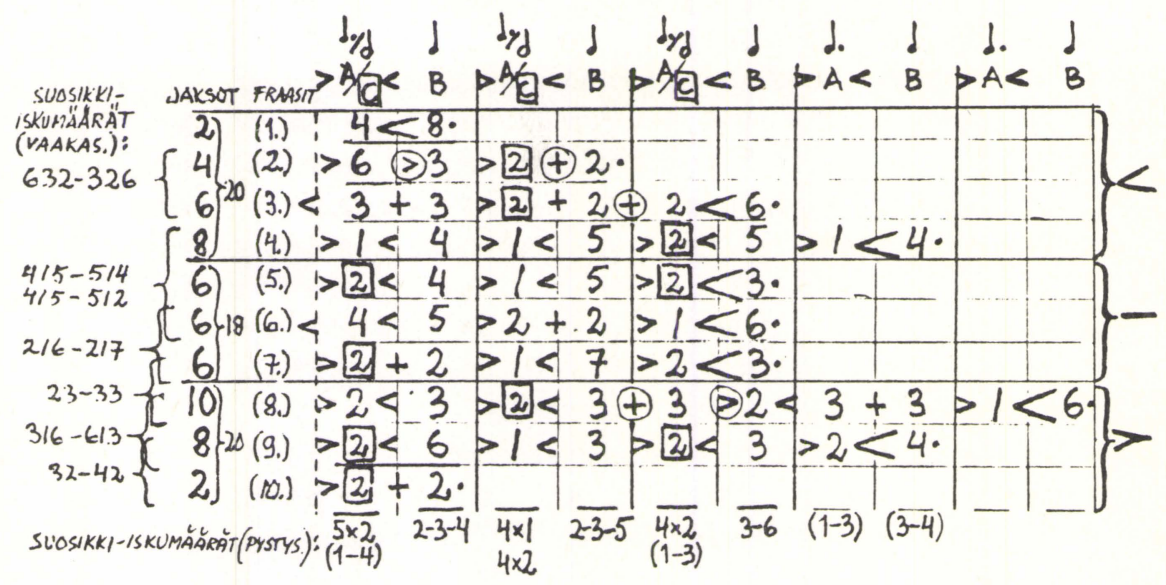

Kuva 36

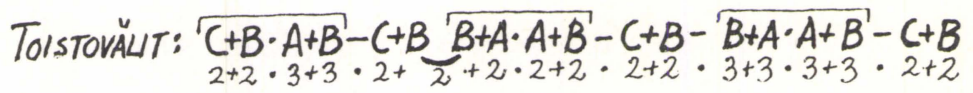

Kuva 37

$$
8-\underbrace{264}_{12}-\underbrace{363}_{12}-\underbrace{642}_{12}
$$

PYSTYS. SARJA: $28<40>12<29>14<28>6<11>1<6$ 
4) Toistot (=+) jakautuvat puoliksi 1-5 ja 6-10 fraaseille. Lisäksi niissä esiintyy vain 22/33 -yhdistelmiä. Normaalisti toisto osuu laajenevan hahmon tilalle mutta jatkuen kuitenkin supistumalla (kuva 36).

5) Hengitystauot ovat poikkeuksetta B-jaksojen jälkeen (8-264-363-642). Huomionarvoista on, että taukoa edeltää (kahdeksan kertaa) laajeneva jaksopari.

6) Jaksojen pituudet noudattavat (III makrotasolla) laajeneva - suppeneva periaatetta.Poikkeuksen muodostavat vain 2. rivi (jossa ehkä haetaan rytmiä), tauot, kontrastiksi muodostuva toistojen poikkeussarja sekä 8. rivin 33-toisto, joka poikkeukselliseti osuu supistuvan jakson kohdalle. Laajeneminen ja supistuminen ilmenevăt selkeimmin, kun laskemme pystyruorien rivien iskumäärät yhteen (kuva 37).

7) $\mathrm{ABC}$-rivit jakautuvat kolmeen hahmoon (IV makrotaso):

laajeneva: rivit $(1-4=20$ jaksoa tai $) 2-4(18$ jaksoa $)=y h t .54$ iskualaa.

toistuva: rivit 5-7 (18 jaksoa) $=$ yht. 54 iskualaa.

supistuva: rivit $8-10(20$ jaksoa $)=$ yht. 55 iskualaa.

Laskiessamme laajenemismäärät yhteen, saamme tulokseksi 53, jos "väärillä" paikoilla olevat supistukset on huomioitu miinusmerkein. Yhteenlaskettu supistumismäärä (iskualoina) on tällöin 55. Laajenemiset ja supistumiset kumoavat toistensa vaikutuksen. (Jos 1. rivi huomiodaan, on tulos täsmälleen 57/57.)

Yksi ainoa kuva on siis kerralla antanut yksinkertaisen ratkaisun toiseen puoleen leu'ddin arvoituksista. Meidän on vain nähtävä ne piirteet, jotka kulloinkin ovat sivuseikkoja - tässä tapauksessa se, kuinka paljon jaksot laajenevat/supistuvat kussakin yksityistapauksessa. Sehän on tekstin ja improvisoinnin tuotteena yllätykselliseksi "tarkoitettukin". Jokainen meistä tekisi sen oman järjestelmänsä mukaisesti. Sen mekaaninen jäljitteleminen ei ole mielekästä.

\section{Analyysitulosten herättämiä ajatuksia}

1) Improvisoidulla musiikilla täytyy olla rakenne yhtä hyvin kuin sävelletylläkin musiikilla. Rakenteiden monimutkaisuus on musiikin tutkimuksessa usein kuitattu sanalla "epäsäännöllinen". Rakenteiden nimeäminen "sattumanvaraisiksi" ei tee oikeutta improvisoinnille inhimillisen toiminnan muotona.

2) Jos musiikki käsitetään informaatioksi, saavat käsitteet "sääntö" ja "poikkeus" uuden luonteen: sääntö kuvastaa tilastollisesti usein esiintyvää ja poikkeus puolestaan harvoin esiintyvää ilmiötä. Normaalitapauksissa edellisen informaatioarvo on pieni ja jälkimmäisen suuri. Emme siis voi ymmärtää poikkeusta jonain negatiivisena arvona vaan säännön välttämättömänä loogisena kääntöpuolena. Em. sanaparit suuri/pieni ja sääntö/poikkeus ovat suhteellisia termejä, koska kysymyksessä on viestin lähettäjän ja vastaanottajan sisäisten "äänitearkistojen" välinen suhde.

3) Leu'dd on malliesimerkki siitä, kuinka monikerroksellinen sääntö-poikkeus -vuorottelu syntyy mistä tahansa kahdesta ilmiöstä jotka kuuntelukoke- 
muksessa hahmotetaan yhteenliittyneiksi. Eurooppalaisen musiikin I/V -suhde on vain yksi lukemattomista mahdollisuuksista.

4) Saman asian eri näkökulmina sääntö-poikkeus -vuorottelu selittää kerralla kaksi musiikillista ilmiötä yhdestä lähtökohdasta käsin. Tämä antaa entistä paremman mahdollisuuden ymmärtää, miksi jokin musiikillinen hahmo esiintyy ja miksi juuri tietyllä paikalla. Näyttäisi siis siltä, että musiikillisten odotusten, niiden viivästymisten tai täyttymisten sekä yllätysten psykologia saa perustansa suoraan informaatioteoriasta.

5) Mikäli sattumanvaraiselta näyttävässä rakenteessa on salattua säännönmukaisuutta, se todennäköisesti ilmenee tilastollisen analyysin avulla. Tulkintatavasta riippuen tällaiset rakenteet ovat jossakin suhteessa sekä sarjallisia että symmetrisiä. Eripituisten sarjojen sijoittuminen limittäin tekee rakenteet loputtomasti muunteleviksi.

6) Improvisointiin luonnostaan kuuluva "säännön pakeneminen" (= säännön ja poikkeuksen yllätyksellinen vuorottelu) on yhtä kurinalaista kuin jonkin säännön toteuttaminen. Se johtaa - pitkällä aikavälillä - makrotason järjestykseen samoin kuin kruunan ja klaavan heitossa. Mutta analyysi ei millään tavalla tue käsitystä improvisoinnin sattumanvaraisuudesta. Pikemminkin voitaisiin puhua "sattuman" tietoisesta matkimisesta. Tämä näkökulma johdattaa käsityksen improvisoidusta musiikista pelinä esittäjän ja kuuntelijan välillä: konkreettisena vastineena ovat pelit, jotka myős perustuvat yllätyksellisiin iskusarjoihin kuten nyrkkeily, tennis etc.

7) Poikkeus on sitä merkityksellisempi mitä harvemmin se toistuu. Vain ainutkertaiset yksityistapaukset viittaavat kenties sävelmän ulkopuolelle johonkin muuhun yhteisesti tunnettuun musiikkiin. Jonkin hahmon aritmeettinen pituus ei ole merkitsevä. Merkittäväă on, milloin se hahmotetaan "pitkäksi" ja milloin "lyhyeksi". Mitä pitempi itseään toistava jakso on, sită vähemmän informaatiota se antaa ja sitä varmemmin seuraa kuulijan tai soittajan kyllästyminen; soiva hahmo alkaa lähestyă hiljaisuutta (vrt. Bergström 1979, 125). Ajan reaalinen, objektiivinen kesto on siis eri asia kuin informaatiotodellisuuden psykologinen aika.

Esimerkkileu'ddissa C-jakso on harvinaisuutensa vuoksi kiintopiste, jonka ympärillä muut jaksot hengittävät supistumalla ja laajenemalla. Ilmiő toistuu sipulimaisesti peräti viidellă eri tasolla. Ennalta-arvaamattomuus takaa mahdollisuuden mielenkiinnon säilymiselle.

8) Analyysi ei missään tapauksessa tue olettamusta, että laulaja tuottaisi musiikkinsa tietoisesti joidenkin numeromallien mukaan (vrt. Ehrenzweig 1967, 29) tai että kuulija kokisi sen tuolla tavoin. Rakennemalleissa ilmenneiden sääntöjen avulla pystyttäisiin kuitenkin tuottamaan sävellykselle täysin autenttinen teoreettinen jatkuvuus. Valittavana on aina kaksi tietä: pyrimmekö uusin muuntelumallein kohti sääntöjen sallimaa entropiaa vai käytämmekö vain aikaisemmin esiintyneitä rakennemalleja. Siis improvisoimmeko vai toistammeko vain traditiota.

9) Näyttäisi siltä, että sävelletyn musiikin analyysi on perinteisesti hakeutunut sääntöjen etsimiseen, mutta improvisoidun musiikin rakenteet avautuvat siirtämällä huomion painopiste "säännön pakenemisesta" seurauksena oleviin tilastollisiin malleihin ja sitä tietä entropiahakuisuuteen (Moles 1971, 57). 
On selvää, että yksisävelikköä laajemmat asteikot vaativat auetakseen tietokoneanalyysin. Vaikeutena on kuitenkin kuulohahmojen määrittely, sillä informaation lisääntyessä alkavat hahmot vastaanottajan tajunnassa kasautua yleisemmän tason kokonaisuuksi. Ongelma vaatisi kuuntelijan päässä olevien rakennemallien analyysin!

10) Teoriassa kuulija voi kohdistaa huomionsa mihin tahansa teoksen osarakenteeseen. Tăstă syystă analyysin olisi tavoitettava kaikki sävellyksessă esiintyvät 1-0 -muuntujat. Koska kukaan ei voi seurata niiden kaikkien muuntelua yhdellä kertaa, on jokainen osa-analyysi myös erikseen oikea. Jos siis löydämme kauniin mallin yhdelle sääntö-poikkeus -vastakohtaparin sisältävälle muuntujaparille, voivat muut tekijät - sillă kertaa - jäädä kaaokseksi. Niiden epäjärjestys jää tällöin tarkkailtavan hahmoparin taustaksi.

Hahmotusmalleja on tuhansittain, mutta kullakin kerralla on vain yksi oikea; se miten kuulija lopulta hahmottaa kuulemansa. "The question is not what code should we use, but what code do we use" (N. Wiener). Kuulija valitsee kullakin hetkellä vain yhden parin tietoisen tarkastelunsa kohteeksi ja muu jää ulkopuolelle - tiedottoman tarkastelun tasolle (vrt. Jenne 1984, 60; Moles 1971, 21 ja Sloboda 1986, 3). Hahmojen täydellinen puuttuminen ei näytttäisi olevan musiikin ominaisuus vaan pikemmin kuulijan "vika" (vrt. Hofstadter 1980, 364). Näin käynee helposti esimerkkileu'ddin kohdalla. Syynä on pikemminkin sen monimutkaisuus kuin yksinkertaisuus.

11) Jos musiikkia lähestytään informaatiokäsitteen avulla, on se ymmärrettävă myős kommunikaatiomuotona. Pelkkă rakenneanalyysi ei tällőin enäă riitä, vaan analyysin piiriin on kuuluttava myös rakenne kokemuksena. Kokemuksen mikromaailma puolestaan rakentuu säännön ja poikkeuksen 1-0 -vaihtelun tajuamisesta. Säännöksi normaalitapauksessaa hahmotetaan useimmin esiintyvä (= "suuri") jakso. Toistumattoman improvisoidun musiikin kohdalla tämä tarkoittaa sitä, että objektiivista rakennetta ei ole! Musiikin rakenne on väistämättä erilainen kuntelukokemuksen alkuvaiheessa kuin sävellyksen kääntyessä loppua kohti. Se mikä alussa oli kaaosta koetaan lopussa toivottavasti - järjestyksenä. Alkukaaoksen keskellä jokainen eläă lapsen tavoin; koettaa käsittää ensimmäiset ylimalkaiset alkeishahmot, vastakohtaparit ja kehittyy vähitellen kohti eriytynyttä hahmorakennetta

Koko ongelman peruskysymys on oikeastaan se, miten AB-arkistolla varustettu kuulija kokee $A B C B$-musiikin ja miten puolestaan $C$-arkistolla varustettu ihminen kokee $\mathrm{ABAB}-\mathrm{ABCB}$-musiikin. $\mathrm{C}$-osan harvinaisuuteen liittyvä informaatioarvo ei olekaan enää yksiselitteinen. $\mathrm{AB}$-ihminen huomaa pian, että $C$ osuu aina A:n kohdalle. Tämä tieto on hänen avaimensa salaisuuden oveen. C-ihminen puolestaan ei aluksi kykene erottamaan $A B: n$ sisäistä rakennetta. Hänen ongelmansa on $\mathrm{C}$-jaksojen ympäristö. Ajatteleeko $\mathrm{AB}$-ihminen sarjallisesti ja $\mathrm{C}$-ihminen symmetrisesti? Joka tapauksessa $\mathrm{C}$ on $\mathrm{AB}$-ihmiselle aluksi mysteeri mutta $\mathrm{C}$-ihmiselle kiintopiste. ${ }^{5}$ Kummassakin tapauksessa kokemusmaailmat ovat yhtä todellisia, sillä ne muuttuvat todellisiksi meidän reagointimme kautta.

Jos arvokokemus syntyy vasta esittäjän ja kuulijan äänitearkistoiden välisestä suhteesta, ei analyysi voi kertoa mitään objektiivista itse musiikin "taiteellisesta" arvosta. "Monimutkaista" musiikkia on nähtävästi kyetty tekemäăn ihmiskunnan 
historian varhaisvaiheista saakka. Sen funktio on (ennalta-arvaamatonta "salakieltä" käyttävän) improvisoivan esittäjän yksilöllisyyden vahvistamisessa. Ryhmäidentiteettiă vahvistava yhteinen salakieli on văistämăttă yksinkertaisempaa (vrt. Moles 1971, 81 ja Wiener 1962, 92-93). Sen on toistuttava samanlaisena jotta se voidaan opetella ja siirtăă kulttuuriperintőnă eteenpäin. Näin syntyy ykseydentunne ryhmän jäsenten kesken. Viimeinen askel on shamanistinen musiikki, joka on yksiselitteistä, kaikille avointa. Shamaanirummun takominen musiikin yksinkertaisen puolen ääripisteenä johdattaa ykseydentuntoon kaikkeuden kanssa.

\section{Huomautus}

Artikkeli on lyhennelmä laajemmasta käsikirjoituksesta, jonka nimenä on "Leu'dd Huotari ja Matvei Fofonofin tyttären rakkausseikkailuista".

\section{Viitteet}

1. Kreikkalaiset nimittivät Toynbeen $(1950,529)$ mukaan sattumaa Automatiajumalattareksi.

2. Suomen kielen nauhoitearkisto; T.I. Itkonen 1913, lieriö 19.

3. Ikävä kyllä esim. Kansat soittavat -kirjani joiuista ainakin numerot 126, 129 , $130,135,136$ ja 137 ovat osoittautuneet liian yksinkertaisiksi nuotinnoksiksi. Lähes kaikki kirjoitetut puolinuotit ovat todellisuudessa lähempänä pidennettyä neljäsosaa. Viidentoista vuoden joikuharrastus ei ole näköjään riittänyt. Epäilen monen muun tehneen samat virheet.

4. Mitä "objektiivisempi" rakenne on, sitä mahdottomampi sitä on tajuta yhdellä kertaa, koska ko. rakenne olisi kaikkein mahdollisten teoksen sisällä olevien 1-0 muuntujien summa. Kukaan ei kerralla voi tajuta kuin osan siitä; vrt. myös Jauch 1973, 63-65.

5. Sarjan "objektiivinen todellisuus" on merkityksetön, koska se on aina tulkintavalinnan kohteena. Vrt. kuvan 34 kysymysmerkit: Laajeneeko numerosarja äkillisesti vai alkaako se laajana - supistumisen päätyttyä? Entä kuvan kommentit: Onko ABABAB-sarja A:n kannalta AB- vai BAB-tyyppiä. Kun tulkinta on täysin yksiselitteinen, luulemme sen olevan itse todellisuutta.

\section{Lähteet}

Bergström, Matti

1979 Aivojen fysiologiasta ja psyykestä. WSOY. Porvoo.

Broadbent, D.E

1958 Perception and communication. Pergamon Press. London.

Ehrenzweig, Anton

1967 The hidden order of art. University of California Press.

Gottlund, C.A.

1832 Otava II, Tukholma.

Hofstadter, Douglas R.

1980 Gödel, Escher, Bach. Vintage books. New York. 
Itkonen, T. I.

1971 "Koltan-Lapissa kevättalvella 1913". Kalevalaseuran vuosikirja 51, s. 239-259. Ks. myø̋s Joukahainen, Helsinki 1913, s. 169-192. Kuvaus

Jauch, J. M. matkasta, jonka tuloksena oli mm. tässä artikkelissa analysoitu leu'dd.

1973 Are quanta real. Indiana University Press.

Jenne, Miachel

1984 Music, commucation, ideology. Birch Tree Group. Princeton

Koffka, K.

1935 Principles of Gestalt psychology, Harcourt, Brace \& Co.

Kuhn, Alfred

1976 The logic of social systems. Jossey-Bass

Laitinen, Heikki

1977 Suonikylän laulut vuonna l96l. Musiikkitieteen pro gradu, Helsingin yliopisto, musiikkitieteen laitos. Käsikirjoitus.

Langer, Susan

1953 Feeling, and form. New York.

Launis, Armas

1922 Kaipaukseni maa. Gummerus. Jyväskylä.

Meyer, Leonard B.

1956 Emotion and meaning in music. University of Chicago Press, 7 painos.

1967 Music, the Arts and Ideas. University of Chigago Press.

Moles, Abraham A.

1969 Informationstheorie und ästhetische Wahrnehmung. M. Du Mont

Piston, Walter Schauberg, Köln.

1941 Harmony. Norton. New York.

Prigogine, Ilya \& Isabelle Stengers

1984 Order ouf of Chaos. Bantam Books. New York.

Saastamoinen, Ilpo

1985 Kansat soittavat. Tammi. Helsinki.

Schopenhauer, Arthur

1945 "Musiikin metafysiikasta". Pessimistin elämänviisaus. WSOY. Porvoo.

Sloboda, John A.

1986 The musical mind. Oxfor University Press.

Toynbee, Arnold J.

1950 Historia undessa valossa. WSOY. Porvoo.

Wiener, Norbert.

1962 Cybernetics, MIT Press. Cambridge.

1954 The human use of human beings. Doublebay Anchor Books. New York.

\section{Summary}

The leu'dd song of the skolts in Lappland: The entropy of chance or a hidden order?

The subject of the study is an epical Sami song, the leu'dd which is composed by improvizing like a lament. The purpose of the analysis was to find out whether this kind of music is irregular in form and based on change, or whether there are any fixed structures in it. The point of departure here was to conceive the music as information which consists of at least a "1-0" pair of a rule and an exception. This kind of a pair creates prerequisites for "a spiritual game" between the 
performer and the listener. Then attention is paid to the predictability or unpredictability of a series consisting of one pair of opposities - this is comparable to the series of variations in tennis or boxing.

Firstly, the analysis eliminates unexceptionable style traits and the possibility of strophic singing (Fig. 3, 6, and 9). Astonishing proportions are revealed between $1 / 4$ and $1 / 8$ notes (Fig. 10 and 11). Unusual proportions remain although note-values are organized again into three groups, A, B, and C (Fig. 1214). At the same time we can see the form of the song: the form $A B C B$ (23113) bordered by the pattern $A B$ (Fig 15) where the length of a single $A$ or $B$ cannot be predicted. The micro-analysis of the parts reveals, however, two recurrent aspects: the entropy distribution (Fig. 32) of exceptions that is grouped around the "statistical rule" and the alternation of contraction and expansion that takes place on five levels and is comparable to wave-like movement. This culminates in the balance of "breathing" shown by the table (Fig. 35) which illustrates the stressed rhythmic patterns: the instances of contraction and expansion invalidate each other in a precision comparable to "flipping coins"! However, this is no longer a question of chance; breaking the rules creates unexpected effects which are basically as rigorous as is following the rule.

The analysis leads one to the following conclusions:

- serial structures (ABAB) are generally conceived as rules and symmetries (ABA...) as exceptions.

- rule and exception are both statistical and relative terms: what is a rule for the performer may be an exception for the listener.

- exception is the necessary and logical reverse side of the rule; thus one theory explains two musical phenomena simultaneously.

- the more rarely an exception is repeated, the more meaningful it becomes.

- by following the rules on the micro-level one can generate new music in an authentic style.

- although the listener can only focus his attention on one pair of variables at one time, he is obliged to recompose what he hears by making choices. Thus there are as many analytic interpretations as there are pairs of variables but only one of these is "correct": the one that coincides with the way that the listener mentally restructures what he has heard.

- the crucial issue is how a listener provided with a mental archive "AB" or " $\mathrm{C}$ " decodes the music ABCB.

- to describe the leu'dd as being "primitive" or "simple" does not characterize the music but it characterizes the fact that information that is too complicated has been interpreted as silence.

- as information the improvisation is the secret code of an individual that reinforces his feeling of identity; non-improvised strophic song reinforces the integrity of a group; and the most simple musical form - shamanic drumming reinforces the feeling of unity with the Eternal. As a form of information "0" it guides one to an internal world of ecstasy. 